\title{
The Transcriptome of Rhizobacteria-Induced Systemic Resistance in Arabidopsis
}

\author{
Bas W. M. Verhagen, ${ }^{1}$ Jane Glazebrook, ${ }^{2}$ Tong Zhu, ${ }^{2}$ Hur-Song Chang, ${ }^{2}$ L. C. van Loon, ${ }^{1}$ and \\ Corné M. J. Pieterse ${ }^{1}$ \\ ${ }^{1}$ Graduate School Experimental Plant Sciences, Section Phytopathology, Faculty of Biology, Utrecht University, \\ P.O. Box 800.84, 3508 TB Utrecht, The Netherlands; ${ }^{2}$ Torrey Mesa Research Institute, Syngenta Research and Technology, \\ San Diego, CA 92121, U.S.A.
}

Submitted 10 March 2004. Accepted 27 April 2004.

Plants develop an enhanced defensive capacity against a broad spectrum of plant pathogens after colonization of the roots by selected strains of nonpathogenic, fluorescent Pseudomonas spp. In Arabidopsis thaliana, this rhizobacteria-induced systemic resistance (ISR) functions independently of salicylic acid but requires responsiveness to the plant hormones jasmonic acid and ethylene. In contrast to pathogen-induced systemic acquired resistance, rhizobacteria-mediated ISR is not associated with changes in the expression of genes encoding pathogenesis-related proteins. To identify ISR-related genes, we surveyed the transcriptional response of over 8,000 Arabidopsis genes during rhizobacteria-mediated ISR. Locally in the roots, ISR-inducing Pseudomonas fluorescens WCS417r bacteria elicited a substantial change in the expression of 97 genes. However, systemically in the leaves, none of the approximately 8,000 genes tested showed a consistent change in expression in response to effective colonization of the roots by WCS417r, indicating that the onset of ISR in the leaves is not associated with detectable changes in gene expression. After challenge inoculation of WCS417r-induced plants with the bacterial leaf pathogen $P$. syringae pv. tomato DC3000, 81 genes showed an augmented expression pattern in ISR-expressing leaves, suggesting that these genes were primed to respond faster or more strongly upon pathogen attack. The majority of the primed genes was predicted to be regulated by jasmonic acid or ethylene signaling. Priming of pathogen-induced genes allows the plant to react more effectively to the invader encountered, which might explain the broad-spectrum action of rhizobacteria-mediated ISR.

Additional keywords: transcript profiling.

Selected strains of root-colonizing, fluorescent Pseudomonas spp. have been shown to trigger a plant-mediated resistance response in aboveground plant parts. This type of induced resis-

Corresponding author: Corné M. J. Pieterse; Telephone: +31 30253 6887; Fax: +31 30251 8366; E-mail: C.M.J.Pieterse@ bio.uu.nl

Current address of J. Glazebrook: Dept. of Plant Biology, University of Minnesota, 220 BioSci Center, 1445 Gortner Ave., St. Paul 55108, U.S.A.

Current address of T. Zhu: Syngenta Biotechnology, Inc., 3054 Cornwallis Road, Research Triangle Park, NC 27709, U.S.A.

Current address of H.-S. Chang: Diversa Corporation, 4955 Directors Place, San Diego, CA 92121, U.S.A.

* The $\boldsymbol{e}$-Xtra logo stands for "electronic extra" and indicates the HTML abstract available on-line contains a supplemental table not included in the print edition. tance is referred to as rhizobacteria-mediated induced systemic resistance (ISR) (Van Loon et al. 1998). Phenotypically, rhizobacteria-mediated ISR resembles classical pathogen-induced systemic acquired resistance (SAR), in which noninfected parts of locally infected plants become more resistant to further infection (Ross 1961). Pseudomonas fluorescens strain WCS417 $r$ has been shown to effectively trigger ISR in several plant species (e.g., carnation [Van Peer et al. 1991], radish [Leeman et al. 1995], tomato [Duijff et al. 1998], bean (Bigirimana and Höfte 2002], and Arabidopsis thaliana [Pieterse et al. 1996, 2002]). Colonization of Arabidopsis roots by WCS417r protects the plant systemically against different types of pathogens, including the bacterial leaf pathogens Pseudomonas syringae pv. tomato and Xanthomonas campestris pv. armoraciae, the fungal root pathogen Fusarium oxysporum f. sp. raphani, the fungal leaf pathogen Alternaria brassicicola, and the oomycete leaf pathogen Peronospora parasitica (Pieterse et al. 1996; Ton et al. 2002b; Van Wees et al. 1997). The spectrum of effectiveness of WCS417r-mediated ISR and pathogen-induced SAR overlaps, but also is partly divergent. For instance, SAR is effective against Turnip crinkle virus, whereas ISR is not. Conversely, ISR is effective against $A$. brassicicola, whereas SAR is not (Ton et al. 2002b). In the case of $P$. syringae pv. tomato DC3000, which is affected by both ISR and SAR, the level of induced resistance can be enhanced further when both types of induced resistance are activated simultaneously (Van Wees et al. 2000), indicating that the effects of ISR and SAR are additive.

Although both rhizobacteria-mediated ISR and pathogen-induced SAR are each effective against a broad spectrum of pathogens, their signal-transduction pathways are clearly distinct. The onset of SAR is accompanied by a local and systemic increase in the endogenous levels of salicylic acid (SA) (Malamy et al. 1990; Métraux et al. 1990) and the concomitant up-regulation of a large set of genes, including those encoding pathogenesis-related (PR) proteins (Maleck et al. 2000; Ward et al. 1991). Several PR proteins possess antimicrobial activity and are thought to contribute to the state of resistance attained (Van Loon and Van Strien 1999). Transduction of the SA signal requires the function of the regulatory protein NPR1 (also known as NIM1) (Cao et al. 1994; Delaney et al. 1995; Shah et al. 1997). Interaction of NPR1 with the b-ZIP transcription factor TGA2 is required for activation of the SA-regulated gene $P R-1$, suggesting that NPR1 acts by altering the activity of transcription factors (Fan and Dong 2002). In contrast to SAR, WCS417r-mediated ISR functions independently of SA. This was demonstrated by the observation that Arabidopsis genotypes that are impaired in SA accumulation (i.e., NahG, 
eds5, and sid2) display levels of ISR equal to those of wild-type plants upon colonization of the roots by WCS417r (Pieterse et al. 1996, 2002; Ton et al. 2002a). Analysis of the jasmonic acid (JA)-response mutant jarl-1, a range of ethylene (ET)response mutants, and the SAR-compromised mutant nprl-1 revealed that components of the JA and ET response are required for triggering ISR and that this induced resistance response, like SAR, depends on NPR1 (Knoester et al. 1999; Pieterse et al. 1998). However, downstream of NPR1, the ISR and the SAR signaling pathways diverge because, unlike SAR, ISR is not accompanied by the concomitant activation of $P R$ genes (Pieterse et al. 1996; Van Wees et al. 1997, 1999).

Apart from WCS417r, other fluorescent Pseudomonas spp. strains also have been shown to induce the SA-independent ISR pathway in Arabidopsis spp. (Iavicoli et al. 2003; Ryu et al. 2003; Van Wees et al. 1997), tobacco (Press et al. 1997; Zhang et al. 2002), and tomato (Yan et al. 2002), indicating that the ability to trigger an SA-independent pathway controlling systemic resistance is not uncommon among ISR-inducing rhizobacteria. However, not all resistance-inducing rhizobacteria trigger an SA-independent resistance. For instance, an SA-overproducing mutant of Pseudomonas aeruginosa 7NSK2 and the genetically modified, SA-overproducing $P$. fluorescens strain P3 have been shown to trigger the SA-dependent SAR pathway by producing SA at the root surface (De Meyer and Höfte 1997; Maurhofer et al. 1998).

In Arabidopsis spp., both JA and ET activate specific sets of defense-related genes (Schenk et al. 2000) and, when applied exogenously, both can induce resistance (Pieterse et al. 1998; Van Wees et al. 1999). To investigate whether ISR is associated with changes in JA- or ET-responsive gene expression, Van Wees and associates (1999) monitored the expression of a set of well-characterized JA- or ET-responsive genes (i.e., LOX1, LOX2, VSP, PDF1.2, HEL, CHI-B, and PAL1) in Arabidopsis plants expressing WCS417r-mediated ISR. None of the genes tested was up-regulated in induced plants, neither locally in the roots nor systemically in the leaves. This suggests that the resistance attained was not associated with major increases in the levels of either JA or ET. Indeed, analysis of JA and ET levels in leaves of ISR-expressing plants revealed no changes in the production of these signal molecules (Pieterse et al. 2000). Therefore, it was assumed that the JA and ET dependency of ISR is based on enhanced sensitivity to these hormones, rather than on an increase in their production.

The onset of SAR is accompanied by substantial transcriptional reprogramming (Maleck et al. 2000), resulting in the accumulation of $P R$-gene products to levels from 0.3 to $1 \%$ of the total mRNA and protein content (Lawton et al. 1995). Although resulting in a similar enhanced resistance against different types of pathogens, ISR has not been associated with changes in gene expression, but should be likewise dependent on additional defensive activity (Pieterse et al. 2002; Van Wees et al. 1999). Therefore, plants must possess as yet undiscovered defense-related genes, whose products contribute to the broadspectrum resistance associated with ISR. To identify novel defense-related genes that potentially are involved in rhizobacteria-mediated ISR, we determined expression levels of approximately 8,000 genes, representing approximately onethird of the Arabidopsis genome, in ISR-expressing plants at different time points before and after challenge inoculation with the pathogen $P$. syringae pv. tomato DC3000. Analysis of the expression patterns revealed 97 genes that show a substantial change in the level of expression in the roots upon colonization by WCS417r. In contrast, in the leaves, none of the approximately 8,000 genes showed a consistent change in expression level, indicating that the onset of ISR in the leaves is not associated with detectable changes in gene expression.
However, after pathogen challenge, a large set of pathogenresponsive genes showed a specific or augmented change in the level of expression in the ISR-expressing plants. These results indicate that ISR-expressing plants are primed to react faster to pathogen challenge.

\section{RESULTS}

\section{Transcript profile of Arabidopsis roots colonized by ISR-inducing $P$. fluorescens WCS417r.}

To determine the transcript profile of Arabidopsis roots in response to colonization by ISR-inducing WCS417r bacteria, 2week-old seedlings of Arabidopsis accession Col-0 were cultivated in a rock-wool-based system. This system previously was demonstrated to be well-suited for studying ISR in Arabidopsis (Pieterse et al. 1996; Van Wees et al. 1997) and has the advantage that clean root material can be collected easily for RNA extraction. For induction of ISR, a suspension of WCS417r bacteria in $10 \mathrm{mM} \mathrm{MgSO}_{4}$, mixed with talcum powder as a carrier, was applied to the roots. As a control, $10 \mathrm{mM} \mathrm{MgSO}_{4}$ was applied in a similar manner. Systemic protection in ISR-expressing plants results from the continuous stimulation of the plant by ISR-inducing rhizobacteria on the root surface. In Arabidopsis, full expression of WCS417r-mediated ISR in the leaves can be detected within 7 days after treatment of the roots with this rhizobacterial strain (Ton et al. 2002b; data not shown). Therefore, to survey the transcript profile of roots of Arabidopsis plants during the onset of ISR, root samples were collected at 3 and 7 days after the start of WCS417r treatment.

RNA was prepared from two independent biological replicates, each consisting of approximately 75 root systems. These two replicates were pooled to reduce noise arising from variation in experimental conditions. The transcript profile of each pool was obtained by hybridization of an Affymetrix Arabidopsis GeneChip microarray representing approximately 8,000 Arabidopsis genes (Zhu and Wang 2000). On this microarray, each gene is represented by at least one "probe set" consisting of 16 to 20 25-mer oligonucleotides. After hybridization, expression values from each pooled sample were normalized globally. To validate the global normalization, the fold change in expression level of a set of 10 genes previously identified as representative, constitutively expressed controls (Kreps et al. 2002), was calculated. As expected, the fold change ratio in WCS417r- over mock-treated roots was close to 1 for most of these genes (Table 1).

To identify WCS417r-responsive genes, the following conservative selection criteria were applied. First, the expression level had to be $>40$ in at least one of the data sets. Second, the change in expression level in WCS417r-treated roots compared with that in mock-treated roots had to be at least twofold. Under these conditions, the technical false positive rate is approximately $0.25 \%$, representing approximately 20 genes among the 8,000 genes analyzed by the GeneChip (Zhu and Wang 2000). A total of 1,691 probe sets met these two conditions on at least one time point after treatment of the roots with WCS417r. However, to avoid false positives, we required the changes to occur at both time points in the same direction. Therefore, only those probe sets were selected that met these selection criteria at both time points tested. Finally, 102 probe sets representing 97 genes met these stringent selection conditions, the majority of which were down-regulated (62\%) (Table 2 ). Of the 97 genes that showed consistent changes, $18 \%$ are annotated as "unclassified proteins", $18 \%$ are predicted to be involved in cell rescue and defense, $14 \%$ in metabolism, $15 \%$ in regulating gene transcription, and $7 \%$ in cellular communication and signal transduction. In view of the ET dependency of ISR, genes encoding a putative ACC oxidase, ET response 
factor 1 (ERF1), and ET responsive element binding factors 1 (EREBP1) and 2 (EREBP2) are of particular interest. Among all of the WCS417r-responsive genes, the transcript for a putative flavonol reductase was observed as the most strongly induced (i.e., over 14-fold).

To verify the GeneChip results, we selected two up-regulated genes encoding an MYB-like transcription factor (MYB72; probe set 12725_r_at) and an unknown "expressed protein" (probe set 18721_at), a down-regulated gene encoding an MLO-like protein (MLO8; probe set 13687_s_at), a gene with unchanged expression encoding vegetative storage protein 2 (VSP2; probe set 14675_s_at), and a gene encoding a glucosyltransferase, of which the transcript levels were below the detection level of the GeneChip (probe set 17362_at), and analyzed their transcript levels in WCS417rand mock-treated Arabidopsis roots by reverse-transcriptase polymerase chain reaction (RT-PCR). To this end, in an independent experiment, RNA was isolated from roots of 3week-old Col-0 plants that were grown for 7 days in the presence or absence of WCS417r bacteria in the rockwool system. The transcript levels of the selected up-regulated MYB72 transcription factor gene and the unknown "expressed protein" gene clearly were increased in WCS417r-treated roots (Fig. 1), whereas the mRNA level of the selected down-regulated $M L O 8$ gene clearly was lower in WCS417r-treated roots. As expected, transcript levels of the selected VSP2 gene remained unchanged in the roots, whereas the transcript levels of the selected glucosyltransferase gene also were undetectable by RT-PCR. These results confirm the data from the GeneChip experiments.

\section{ISR is not associated with systemic changes in gene expression in the absence of pathogen infection.}

Colonization of the roots of Arabidopsis accession Col-0 by WCS417r results in a systemic resistance in the leaves that is effective against different types of pathogens (Pieterse et al. 2002). To identify genes that show a specific change in expression in the leaves in response to treatment of the roots with ISR-inducing rhizobacteria, 2-week-old Col-0 seedlings were transplanted into soil with or without WCS417r. To examine the expression profile of leaves of induced and noninduced plants, leaf samples were collected 3 and 7 days after induction. Expression of ISR routinely was verified in parallel using our standard bioassay (Pieterse et al. 1996) with the bacterial leaf pathogen $P$. syringae pv. tomato DC3000 as the challenging pathogen (data not shown). RNA was prepared from three independent biological replicates, each consisting of approximately 25 rosettes, that were pooled to reduce noise arising from variation in experimental conditions.
Transcript profiling was performed for two independent experiments on data sets that were normalized globally. Global normalization was validated again by calculating the fold change in expression level of the 10 representative constitutively expressed control genes. The fold change ratio in leaves of WCS417r- over mock-treated plants was close to 1 for most of these genes (Table 3).

To identify genes that respond systemically in the leaves to colonization of the roots by WCS417r, we selected probe sets that had an expression level of $>40$ and that showed a greater than twofold change in ISR-expressing leaves compared with noninduced leaves. The number of probe sets that met these criteria on the single time points varied between 20 and 23, which is close to the technical false positive rate of approximately $0.25 \%$ (Zhu and Wang 2000). To reduce false positives, we required the changes to be consistent at both time points tested or to show reproducibility between experiments. Interestingly, none of the probe sets met the selection criteria. Northern blot analysis of the RNA samples that were used for the GeneChip hybridizations and of RNA samples from similar other experiments confirmed that the transcript levels of several defense-related genes (e.g., CHI-B, HEL, LOX2, PDF1.2, $P R-1, P R-2$, and $P R-5)$ were not increased in the leaves in response to colonization of the roots by ISR-inducing rhizobacteria (Van Wees et al. 1999; data not shown). These results indicate that, although ISR-expressing leaves possess an enhanced defensive capacity, the state of ISR is not associated with detectable changes in the expression of the approximately 8,000 genes represented on the GeneChip.

\section{Selection of $P$. syringae pv. tomato DC3000-responsive genes in control and ISR-expressing plants.}

The observed lack of changes in gene expression in leaves of WCS417r-induced plants suggests that the broad-spectrum effectiveness of ISR might be based on processes that are apparent only after pathogen attack. Previously, Northern blot analyses of the JA-responsive, pathogen-inducible gene VSP2 revealed that ISR is associated with enhanced expression of this gene after infection of the leaves by $P$. syringae pv. tomato DC3000 (Van Wees et al. 1999), suggesting that ISR-expressing plants are primed to express specific pathogen-inducible genes at a higher level after challenge. To investigate the transcript profile of pathogen-responsive genes in ISR-expressing plants, Arabidopsis Col-0 plants grown in soil with or without ISR-inducing WCS417r bacteria were challenge inoculated with $P$. syringae pv. tomato DC3000 and checked for expression of ISR (data not shown). Leaf samples were collected from control and WCS417r-induced plants at 0, 6, and $24 \mathrm{~h}$ after challenge inoculation. RNA was prepared from three

Table 1. Fold-change ratio of representative constitutively expressed control genes in Pseudomonas fluorescens WCS417r-treated compared with mocktreated Arabidopsis roots

\begin{tabular}{|c|c|c|c|c|}
\hline \multirow[b]{2}{*}{ Annotation } & \multicolumn{2}{|c|}{ Fold-change ratio $^{a}$} & \multirow[b]{2}{*}{ Probe set no. } & \multirow[b]{2}{*}{ AGI no. } \\
\hline & 3 days & 7 days & & \\
\hline Polyubiquitin, UBQ10 & 0.66 & 0.57 & 12833_f_at & AT4G05320 \\
\hline Eukcaryotic initiation factor elF-4A1 & 1.66 & 0.98 & 16026_at & AT3G13920 \\
\hline Aquaporin, PIP-1B & 2.74 & 1.15 & 15977_s_at & AT2G45960 \\
\hline V-type $\mathrm{H}^{+}$-ATPase, $16 \mathrm{kD}$-subunit & 2.00 & 0.99 & 15584_s_at & AT1G19910 \\
\hline $40 \mathrm{~S}$ ribosomal protein $\mathrm{S} 16$ & 1.17 & 1.05 & 17390_at & AT2G09990 \\
\hline Actin 2 & 1.71 & 1.21 & 16476_at & AT3G18780 \\
\hline Plasma membrane $\mathrm{H}^{+}$-ATPase, AHA1 & 1.38 & 1.08 & 14713_s_at & AT2G18960 \\
\hline Tubulin, B-4 & 0.72 & 1.33 & 15988_at & AT5G44340 \\
\hline Calmodulin-1 & 1.52 & 1.03 & 15173_f_at & AT5G37780 \\
\hline Ca-dependent protein kinase, CPK3 & 1.57 & 1.15 & 17058_s_at & AT4G23650 \\
\hline Average & 1.5 & 1.1 & $\ldots$ & $\ldots$ \\
\hline
\end{tabular}

${ }^{\text {a }}$ Fold change ratios (WCS417r/mock) are based on gene expression profiles of roots of Col-0 plants at 3 or 7 days after treatment with induced systemic resistance-inducing WCS417r bacteria or $10 \mathrm{mM} \mathrm{MgSO}_{4}$ (mock). 
independent biological replicates, each consisting of approximately seven rosettes, that were pooled to reduce noise arising from variation in experimental conditions. To identify $P$. syringae pv. tomato DC3000-responsive genes in noninduced and in ISR-expressing plants, probe sets were selected that showed an expression level of $>40$ and a greater than twofold change at 6 or $24 \mathrm{~h}$ after pathogen inoculation compared with nonchallenged plants. A total of 1,661 probe sets satisfied this condition in noninduced plants, whereas 1,507 probe sets met the selection criteria in WCS417r-induced plants. The lower number of selected probe sets from the data set of WCS417rinduced plants correlated with the observed reduction of disease symptoms in the ISR-expressing plants (data not shown). Only those probe sets were selected that met the above-mentioned selection criteria at both 6 and $24 \mathrm{~h}$ after challenge inoculation, resulting in a total of 523 probe sets representing 469 genes in noninduced plants, and 479 probe sets representing 425 genes in WCS417-induced plants.

Table 2. Fold-change ratio of Pseudomonas fluorescens WCS417r-responsive genes in WCS417r-treated compared with mock-treated Arabidopsis roots

\begin{tabular}{|c|c|c|c|c|}
\hline \multirow[b]{2}{*}{ Annotation $^{\mathbf{b}}$} & \multicolumn{2}{|c|}{ Fold-change ratio $^{a}$} & \multirow[b]{2}{*}{ Probe set no. } & \multirow[b]{2}{*}{ AGI no. } \\
\hline & 3 days & 7 days & & \\
\hline \multicolumn{5}{|l|}{ Transcription } \\
\hline Myb family transcription factor & 7.4 & 3.4 & 18479_at & AT3G12820 \\
\hline Identical to WRKY transcription factor 31 & 3.0 & 2.4 & 18213_at & AT4G22070 \\
\hline Myb family transcription factor (MYB72) & 2.8 & 3.1 & 12725_r_at & AT1G56160 \\
\hline GATA zinc finger protein & 2.3 & 3.7 & 13168_i_at & AT2G45050 \\
\hline Putative chloroplast nucleoid DNA binding protein & 2.2 & 2.1 & 15720_at & AT2G03200 \\
\hline Myb family transcription factor (MYB88) & -2.5 & -2.9 & 14852_s_at & AT2G02820 \\
\hline Putative $\mathrm{C} 2 \mathrm{H} 2$-type zinc finger protein & -2.5 & -2.1 & 20620_g_at & AT2G37430 \\
\hline CONSTANS B-box zinc finger family protein & -2.7 & -2.1 & 19855_at & AT1G78600 \\
\hline No apical meristem (NAM) protein family & -2.8 & -2.0 & 18590_at & AT1G69490 \\
\hline Myb family transcription factor & -3.4 & -2.5 & 19707_s_at & AT5G67300 \\
\hline RING-H2 finger protein RHA1a -like protein & -3.7 & -2.2 & 16130_s_at & AT4G11370 \\
\hline Ethylene response factor 1 & -6.0 & -2.2 & 17514_s_at & AT3G23240 \\
\hline Putative MYB family transcription factor (MYB25) & -6.3 & -2.4 & 17606_s_at & AT2G39880 \\
\hline Ethylene responsive element binding factor 2 & -8.7 & -2.3 & 16609_at & AT5G47220 \\
\hline Ethylene responsive element binding factor 2 & -24.9 & -3.3 & 12905_s_at & AT5G47220 \\
\hline Ethylene responsive element binding factor 1 & -59.1 & -2.6 & 12904_s_at & AT4G17500 \\
\hline \multicolumn{5}{|l|}{ Cell rescue and defense } \\
\hline Peroxidase & 4.1 & 3.9 & 19622_g_at & AT5G42180 \\
\hline Putative protein & 3.5 & 2.3 & 13973_at & AT4G36980 \\
\hline Peroxidase, putative & 3.3 & 3.1 & 12386_at & AT1G44970 \\
\hline RAS-related GTP-binding protein (ARA-1) & 3.3 & 2.1 & 18195_at & AT1G05810 \\
\hline Drought-induced protein like (Di21) & 2.2 & 2.1 & 18231_at & AT4G15910 \\
\hline Polyubiquitin (UBQ4) & -2.4 & -2.7 & 12830_f_at & AT5G20620 \\
\hline Peroxidase ATP5a & -2.4 & -2.5 & 19602_at & AT1G49570 \\
\hline Expressed protein & -2.6 & -3.1 & 15083_at & AT4G32190 \\
\hline Expressed protein & -2.8 & -2.0 & 12114_at & AT4G39680 \\
\hline Pathogenesis-related protein 1 precursor & -2.9 & -3.1 & $18451 \_s \_$at & AT4G33710 \\
\hline Cytochrome P450 & -3.0 & -2.0 & 14248_at & AT3G26830 \\
\hline Polyubiquitin (UBQ4) & -3.1 & -3.0 & 12831_f_at & AT5G20620 \\
\hline Peroxidase, putative & -3.6 & -2.6 & 12475_at & AT5G06730 \\
\hline Zinc finger protein 5, ZFP5 & -4.0 & -2.8 & 16582_s_at & AT1G10480 \\
\hline Seven transmembrane MLO protein family (MLO8) & -4.8 & -3.3 & 13687_s_at & AT2G17480 \\
\hline Pathogenesis-related protein 1 precursor & -5.1 & -2.5 & 20308_s_at & AT4G33720 \\
\hline Heavy-metal-associated domain-containing protein & -8.3 & -2.4 & 14485_at & AT1G01490 \\
\hline Germin-like protein (GLP10) & -8.7 & -4.5 & 17037_s_at & AT3G62020 \\
\hline \multicolumn{5}{|l|}{ Systemic regulation of or/ interaction with cellular environment } \\
\hline Similar to gibberellin-regulated proteins & 3.9 & 2.9 & 19863_at & AT2G14900 \\
\hline GAST1 protein homolog & 3.6 & 2.6 & 15121_s_at & AT1G75750 \\
\hline GAST1 protein homolog & 3.5 & 2.7 & 16014_s_at & AT1G75750 \\
\hline Putative amino-cyclopropane-carboxylic acid oxidase & 2.5 & 2.0 & 18310_at & AT1G12010 \\
\hline Gibberellin 3 beta-hydroxylase, putative (GA4) & -2.9 & -8.2 & 17549_at & AT1G15550 \\
\hline LAX1/AUX1-like permease & -3.7 & -2.1 & 18667_at & AT5G01240 \\
\hline Terpene synthase/cyclase family & -5.7 & -2.2 & 17511_s_at & AT1G61120 \\
\hline \multicolumn{5}{|l|}{ Cellular communication or signal transduction } \\
\hline Leucine rich repeat family & 9.0 & 4.0 & 16408_at & AT4G18760 \\
\hline Expressed protein & 2.6 & 2.1 & 12154_at & AT2G35190 \\
\hline Expressed protein & -2.6 & -2.4 & 14096_at & AT1G76960 \\
\hline CBL-interacting protein kinase 4 & -3.5 & -2.0 & $12395 \_s \_$at & AT4G14580 \\
\hline Protein kinase (ADK1) & -3.9 & -3.0 & 15692_s_at & AT1G03930 \\
\hline Putative protein/phospholipase C & -6.1 & -2.0 & 12213_at & AT4G34920 \\
\hline Putative protein/leucine-rich-repeat protein & -9.0 & -2.3 & 15249_at & AT4G29880 \\
\hline \multicolumn{5}{|l|}{ Metabolism } \\
\hline Dihydroflavonol 4-reductase (dihydrokaempferol 4-reductase) family & 14.4 & 14.3 & 18198_at & AT2G45400 \\
\hline Terpene synthase/cyclase family & 9.9 & 2.1 & 18127_at & AT4G20230 \\
\hline 1-deoxy-D-xylulose 5-phosphate reductoisomerase (DXR) & 8.8 & 2.5 & 12218_at & AT5G62790 \\
\hline \multirow[t]{2}{*}{ Short chain dehydrogenase/reductase family protein (b-keto acyl reductase, putative) } & 3.0 & 2.2 & 17378_at & AT1G67730 \\
\hline & & & \multicolumn{2}{|c|}{ (continued on next page } \\
\hline
\end{tabular}

${ }^{\text {a }}$ Fold-change ratios (WCS417r/mock) are based on gene expression profiles of roots of Col-0 plants, 3 and 7 days after treatment with $10 \mathrm{mM} \mathrm{MgSO}{ }_{4}$ (mock) or induced systemic resistance-inducing WCS417r bacteria.

${ }^{\mathrm{b}}$ Annotations are as predicted by the MIPS Arabidopsis thaliana Genome Database. 
ISR-expressing plants are primed

for augmented pathogen-responsive gene expression.

Having identified $P$. syringae pv. tomato DC3000-responsive genes, we tested our hypothesis that ISR-expressing plants are primed to respond faster or with a greater magnitude to pathogen infection. To this end, we compared the expression levels of the $P$. syringae pv. tomato DC3000responsive genes in noninduced and ISR-expressing plants. To identify P. syringae pv. tomato DC3000-responsive genes that show an augmented expression pattern in ISR-expressing plants (so-called ISR-primed genes), we required the change in expression level of the $P$. syringae pv. tomato DC3000responsive genes to be $>1.5$-fold higher in the WCS417rtreated plants. This latter criterion was based on quantitative expression data of the VSP2 gene, which previously was demonstrated to be primed in ISR-expressing plants (Van Wees et al. 1999). In several independent experiments, VSP2 transcripts consistently accumulated to an approximately 1.5 -

Table 2. (continued from preceding page)

\begin{tabular}{|c|c|c|c|c|}
\hline \multirow[b]{2}{*}{ Annotation } & \multicolumn{2}{|c|}{ Fold-change ratio } & \multirow[b]{2}{*}{ Probe set no. } & \multirow[b]{2}{*}{ AGI no. } \\
\hline & 3 days & 7 days & & \\
\hline \multicolumn{5}{|l|}{ Metabolism (continued) } \\
\hline FAD-linked oxidoreductase family & 2.3 & 2.4 & 13622_i_at & AT4G20820 \\
\hline Glycosyl hydrolase family 1 & -2.2 & -2.1 & 16778_at & AT2G44480 \\
\hline Glycine-rich RNA binding protein (AtGRP7) & -2.5 & -2.6 & 15105_s_at & AT2G21660 \\
\hline Putative tyrosine aminotransferase & -3.0 & -2.3 & 17008_at & AT2G24850 \\
\hline Copper amine oxidase-like protein & -3.9 & -2.0 & 20555_s_at & AT4G12280 \\
\hline Glycosyltransferase family 20 & -4.7 & -2.4 & 13706_s_at & AT2G18700 \\
\hline Geranylgeranyl pyrophosphate synthase (ggps6) & -5.8 & -4.6 & 13257_s_at & AT1G49530 \\
\hline S-adenosylmethionine decarboxylase & -6.7 & -2.3 & 16437_s_at & AT3G02470 \\
\hline Lipase (class 3 ) family & -6.9 & -2.6 & 14358_s_at & AT4G16820 \\
\hline Ferrochelatase-I & -8.3 & -3.0 & 12571_s_at & AT5G26030 \\
\hline \multicolumn{5}{|l|}{ Protein synthesis } \\
\hline Translation initiation fact. eIF-2 gamma subunit, putative & -11.1 & -3.0 & 17941_at & AT2G18720 \\
\hline Putative translation initiation factor eIF-2B delta subunit & -29.5 & -2.5 & 16255_at & AT2G44070 \\
\hline \multicolumn{5}{|l|}{ Transport facilitation } \\
\hline Unknown protein/cation transport protein & 3.0 & 3.2 & 15544_at & AT4G31290 \\
\hline Zinc transporter (ZIP2) & 2.3 & 2.0 & 15666_s_at & AT5G59520 \\
\hline Monooxygenase family & -3.0 & -2.5 & 17051_s_at & AT2G29720 \\
\hline Glucose-6-phosphate/phosphate-translocator precursor, putative & -9.6 & -2.1 & $17775 \_$at & AT1G61800 \\
\hline DNA damage-inducible protein (EDS5/SID1) & -14.0 & -3.5 & 17653_at & AT4G39030 \\
\hline \multicolumn{5}{|l|}{ Cell cycle and DNA processing } \\
\hline Putative AAA-type ATPase & 2.1 & 2.0 & 16345_at & AT2G03670 \\
\hline Unknown protein & -3.3 & -2.3 & 14130_at & AT1G03080 \\
\hline \multicolumn{5}{|l|}{ Development (systemic) } \\
\hline Nodulin-like protein (mtn21) & 2.5 & 7.6 & 16258_at & AT2G39510 \\
\hline \multicolumn{5}{|l|}{ Control of cellular organization } \\
\hline Actin depolymerizing factor-like protein & 7.1 & 9.8 & 19684_at & AT4G34970 \\
\hline Small heat shock protein & 2.1 & 2.5 & $13282 \_s \_$at & AT4G25200 \\
\hline \multicolumn{5}{|l|}{ Energy } \\
\hline Expressed protein & 2.9 & 2.1 & 15851_i_at & AT2G27370 \\
\hline Nitrate reductase 2 (NR2) & -5.8 & -3.8 & 14242_s_at & AT1G37130 \\
\hline Nitrate reductase 1 (NR1) & -14.1 & -11.4 & 14240_s_at & AT1G77760 \\
\hline Nitrate reductase 1 (NR1) & -41.7 & -9.0 & 18899_s_at & AT1G77760 \\
\hline \multicolumn{5}{|l|}{ Subcellular localization } \\
\hline Unknown protein & -6.3 & -3.2 & 14524_s_at & AT1G65580 \\
\hline \multicolumn{5}{|l|}{ Cell fate } \\
\hline Expressed protein & 9.5 & 9.8 & 18721_at & AT3G02040 \\
\hline Expressed protein & -2.5 & -2.8 & 18346_at & AT4G35890 \\
\hline \multicolumn{5}{|l|}{ Protein fate (folding, modification, destination) } \\
\hline DegP protease & -2.1 & -2.3 & 16067_at & AT3G27925 \\
\hline Putative DnaJ protein & -11.7 & -6.2 & 15367_at & AT1G76700 \\
\hline Serine carboxypeptidase -related & -27.8 & -3.4 & 18132_at & AT4G15100 \\
\hline \multicolumn{5}{|l|}{ Unclassified proteins } \\
\hline Lateral organ boundaries (LOB) domain family & 9.2 & 2.4 & 15808_at & AT2G30130 \\
\hline Auxin-induced protein-related & 4.3 & 4.1 & 15017_at & AT2G24400 \\
\hline Auxin-induced protein-related & 4.2 & 3.2 & 16751_at & AT4G34750 \\
\hline Putative OBP32pep protein & 3.5 & 9.7 & 13855_at & AT1G23590 \\
\hline Putative protein & 3.5 & 3.0 & 20487_at & AT4G34810 \\
\hline Glucose-methanol-choline (GMC) oxidoreductase family & 2.7 & 3.8 & 19068_i_at & AT1G14185 \\
\hline Expressed proteins & 2.5 & 3.1 & 14436_at & AT3G50750 \\
\hline Unknown protein & 2.3 & 2.1 & 15861_at & AT2G35850 \\
\hline Expressed protein & 2.3 & 2.2 & 15918_at & AT1G30750 \\
\hline Expressed protein & 2.1 & 2.4 & 12163_at & AT2G42780 \\
\hline Putative protein & -2.0 & -9.5 & 13963 at & AT4G18890 \\
\hline RWP-RK domain containing protein & -2.1 & -2.5 & 14521_at & AT4G38340 \\
\hline Kelch repeat containing F-box protein family & -2.2 & -2.1 & 12695_at & AT4G38940 \\
\hline Cytochrome p450 family & -2.7 & -3.0 & 18951_at & AT4G15330 \\
\hline Expressed protein & -3.9 & -2.6 & 15933 at & AT1G21830 \\
\hline Expressed protein & -5.0 & -2.6 & 18160_at & AT4G16745 \\
\hline Putative protein & -5.3 & -2.0 & 20179_at & AT4G38060 \\
\hline Putative tropinone reductase & -73.1 & -2.6 & 20370_at & AT2G29150 \\
\hline
\end{tabular}


fold higher level in P. syringae pv. tomato DC3000-inoculated, ISR-expressing plants than in similarly inoculated control plants (data not shown). Therefore, to select for ISRprimed genes, we required their expression levels to be at least 1.5 -fold higher in WCS417r-treated plants. Note that, in addition to this selection criterion, the $P$. syringae pv. tomato DC3000-responsive genes already were preselected to show an expression level of $>40$ and a greater than twofold change at both 6 and $24 \mathrm{~h}$ after infection.

A comparison of the changes in transcript levels of the ISRprimed, $P$. syringae pv. tomato DC3000-responsive genes in control and ISR-expressing Col-0 plants is depicted in Figure 2. A total of 52 probe sets representing 51 genes met the selection conditions (Table 4). The previously identified ISRprimed, $P$. syringae pv. tomato DC3000-responsive gene VSP2 was among those in this group, illustrating the validity of this analysis. Other ISR-primed genes of particular interest are the JA- and ET-responsive gene PDF1.2, a thaumatin-like gene, a chitinase gene, and a gene encoding EREBP2. In addition to the 51 selected ISR-primed genes, 30 genes showed a $P$. syringae pv. tomato DC3000-induced change in WCS417r-treated plants only; in noninduced plants, the mRNA levels of the corresponding genes remained unchanged after pathogen infection (Fig. 2; Table 5). Apparently, these genes respond to $P$. syringae pv. tomato DC3000 infection only in ISR-induced plants. This latter group is further referred to as ISR-specific. Of the 30 ISR-specific genes, 6 are annotated as "unclassified proteins", 5 are predicted to be involved in metabolism, and 4 genes are likely to be involved in regulating gene transcription (Table 5). Moreover, five genes are predicted to be involved in signal transduction. One of those shows homology to ERF1, which encodes a transcription factor that acts downstream of ET and JA signaling and has been implicated in the defense response of Arabidopsis against various pathogens (BerrocalLobo et al. 2002; Lorenzo et al. 2003; Solano et al. 1998).

To verify the GeneChip data, we examined the expression levels of the $P$. syringae pv. tomato DC3000-responsive gene VSP1 (probe set 15125_f_at), the ISR-primed P. syringae pv. tomato DC3000-responsive genes PDF1.2 (probe set 14621_at) and VSP2 (probe set 14675_s_at), and the constitutively expressed ubiquitin gene UBQ10 (probe set 12835_f_at) in an independent experiment. To this end, Northern blot analysis was performed using RNA from leaves of 5-week-old control and ISR-expressing plants that were harvested 0 and $24 \mathrm{~h}$ after inoculation with $P$. syringae pv. tomato DC3000. Transcript levels of VSP1, VSP2, and
PDF 1.2 clearly were increased in response to $P$. syringae pv. tomato DC3000 infection (Fig. 3), whereas the expression of $U B Q 10$ remained unchanged. Moreover, VSP2 and PDF1.2 showed a clearly enhanced level of expression in challenged ISR-expressing plants over challenged control plants, whereas the $P$. syringae pv. tomato DC3000-induced expression level of VSPI remained unchanged. The level of enhanced expression of VSP2 and PDF1.2 in challenged ISRexpressing plants over $P$. syringae pv. tomato DC3000-inoculated control plants was similar to that observed in the Gene-

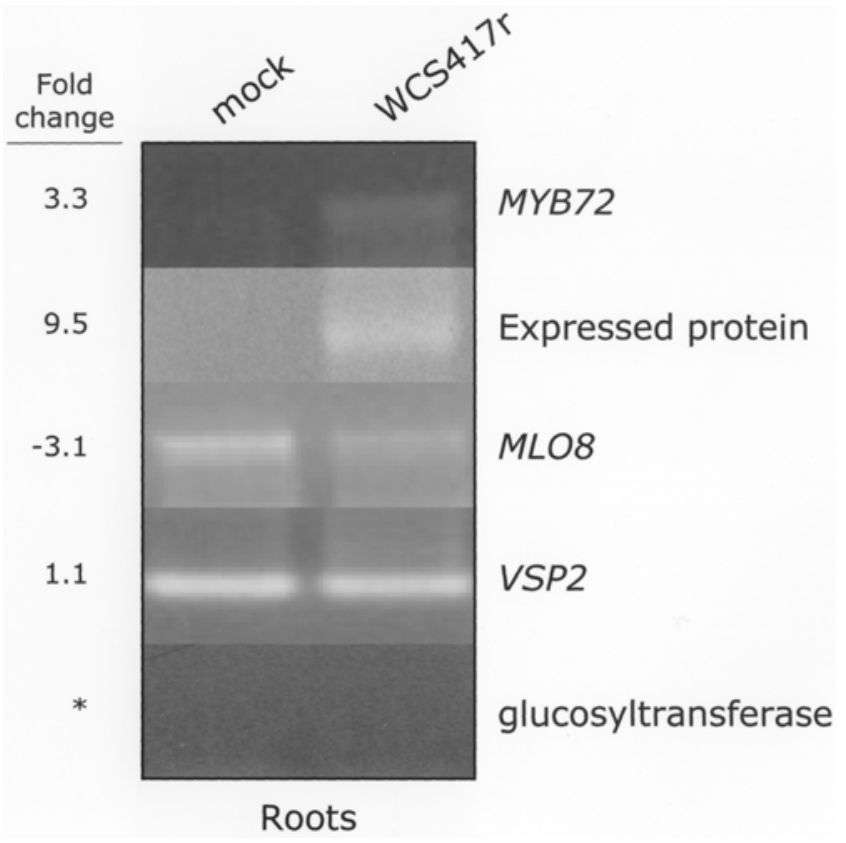

Fig. 1. Verification of root GeneChip data. Transcript levels of genes that were selected in the GeneChip analysis as being up-regulated, downregulated, unchanged (see fold change), or undetectable (asterisk) in WCS417r-treated roots were analyzed by reverse-transcriptase polymerase chain reaction (RT-PCR). Shown are ethidium bromide-stained agarose gels with RT-PCR products obtained after amplification of equal portions of first-strand cDNA using gene-specific primers of the genes indicated (corresponding AGI numbers are AT1G56160, AT3G02040, AT2G17480, AT5G24770, and AT4G15260). First-strand cDNA was synthesized on mRNA that was isolated from roots of Arabidopsis Col-0 plants, 7 days

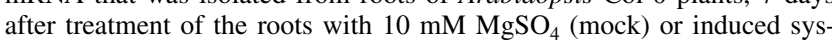
temic resistance-inducing WCS417r bacteria.

Table 3. Fold-change ratio of representative constitutively expressed control genes in leaves of Pseudomonas fluorescens WCS417r-treated compared with mock-treated Arabidopsis plants, before and after challenge inoculation with P. syringae pv. tomato DC3000

\begin{tabular}{|c|c|c|c|c|c|}
\hline \multirow[b]{3}{*}{ Annotation } & \multicolumn{5}{|c|}{ Fold-change ratio } \\
\hline & \multicolumn{2}{|c|}{ Before challenge $^{\mathrm{a}}$} & \multicolumn{3}{|c|}{ After challenge $^{\text {b }}$} \\
\hline & 3 days & 7 days & $\mathbf{O H}$ & $6 \mathrm{~h}$ & $24 \mathrm{~h}$ \\
\hline Polyubiquitin, UBQ10 & 0.79 & 1.08 & 1.05 & 1.39 & 0.85 \\
\hline Eukcaryotic initiation factor elF-4A1 & 1.01 & 1.20 & 1.08 & 1.02 & 0.88 \\
\hline Aquaporin, PIP-1B & 1.03 & 1.12 & 0.94 & 0.98 & 0.94 \\
\hline V-type $\mathrm{H}^{+}$-ATPase, $16 \mathrm{kD}$-subunit & 0.97 & 0.99 & 0.98 & 1.05 & 1.01 \\
\hline 40 S ribosomal protein $\mathrm{S} 16$ & 1.07 & 1.03 & 1.15 & 1.02 & 1.01 \\
\hline Actin 2 & 0.98 & 1.02 & 1.14 & 1.29 & 1.27 \\
\hline Plasma membrane $\mathrm{H}^{+}$-ATPase, AHA1 & 1.43 & 0.79 & 0.96 & 0.99 & 1.23 \\
\hline Tubulin, $\beta-4$ & 1.24 & 1.35 & 1.04 & 0.98 & 0.87 \\
\hline Calmodulin-1 & 1.04 & 1.13 & 0.93 & 0.92 & 1.03 \\
\hline Ca-dependent protein kinase, $\mathrm{CPK} 3$ & 1.08 & 0.64 & 1.04 & 1.06 & 1.01 \\
\hline Average & 1.1 & 1.0 & 1.0 & 1.1 & 1.0 \\
\hline
\end{tabular}

${ }^{a}$ Fold-change ratios (WCS417r/mock) are based on gene expression profiles of leaves of Col-0 plants at 3 and 7 days after treatment of the roots with induced systemic resistance-inducing WCS417r bacteria or $10 \mathrm{mM} \mathrm{MgSO}_{4}$ (mock).

${ }^{\mathrm{b}}$ Fold-change ratios (WCS417r/mock) are based on gene expression profiles of leaves of Col-0 plants, grown in the presence or absence of WCS417r bacteria, at 0,6 , and $24 \mathrm{~h}$ after challenge inoculation with $P$. syringae pv. tomato DC3000. 
Chip data analysis ("ratio" in Table 4). These results agree with and confirm the corresponding data of the GeneChip data analysis.

\section{The role of JA and ET in priming.}

Arabidopsis mutants affected in their ability to respond to either JA or ET are compromised in WCS417r-mediated ISR, indicating that the expression of ISR requires an intact JA and ET signaling pathway (Pieterse et al. 1998, 2002). To investigate the possible role of JA and ET in the regulation of ISRprimed genes, we made use of a microarray data set previously published by Glazebrook and associates (2003). This data set consists of global expression patterns of $P$. syringae pv. maculicola ES4326-induced genes in wild-type Arabidopsis Col-0 and various signaling-defective mutant plants. Previously, Tao and associates (2003) demonstrated that the expression profile of wild-type Col-0 plants inoculated with either $P$. syringae pv. tomato DC3000 or P. syringae pv. maculicola ES4326 is very similar. Therefore, we assumed that the global expression phenotype of $P$. syringae pv. maculicola ES4326-responsive genes is very similar to that of $P$. syringae pv. tomato DC3000-responsive genes. To validate this assumption, we compared the group of $P$. syringae pv. tomato DC3000-responsive genes in control plants with the group of $P$. syringae pv. maculicola ES4326-responsive genes that showed an expression level of $>40$ and a greater than twofold change compared with mockinoculated plants. Of the 523 P. syringae pv. tomato DC3000responsive probe sets that showed a consistent change in expression in noninduced $P$. syringae pv. tomato DC3000infected Col-0 plants, a large group of 278 probe sets $(53 \%)$ showed a similar expression pattern in $P$. syringae pv. maculicola ES4326-infected Col-0 plants. This group of $P$. syringae pv. tomato- and $P$. syringae pv. maculicola-responsive genes was used in the analysis of the data sets that were obtained with the signaling-defective genotypes (see below). The expression level of the remaining $P$. syringae pv. tomato DC3000-responsive genes did not appear to change substantially in $P$. syringae pv. maculicola ES4326-inoculated plants. This might be due to differences in experimental set-up, because the expression profile of the $P$. syringae pv. maculicola ES4326-responsive genes was determined at $30 \mathrm{~h}$ after pressure infiltrating of $P$. syringae pv. maculicola ES4326 into the leaves, whereas our data were collected at 6 and 24 hours after dipping the leaves in a suspension of $P$. syringae pv. tomato DC3000.

To determine the involvement of JA, ET, and SA in the regulation of the ISR-primed, $P$. syringae pv. tomato DC3000responsive genes, we compared their expression profile in $P$. syringae pv. maculicola ES4326-infected wild-type Col-0 plants and the various signaling-defective transgenic or mutant genotypes in the Col-0 background. These genotypes were coil-1, which blocks JA signaling (Feys et al. 1994; Xie et al. 1998); ein2-1, which blocks ET signaling (Alonso et al. 1999; Guzmán and Ecker 1990); and eds5-1 and NahG, which are affected in SA signaling (Gaffney et al. 1993; Nawrath et al. 2002). Of the 51 ISR-primed $P$. syringae pv. tomato DC3000responsive genes, 29 genes $(57 \%)$ also were responsive to $P$. syringae pv. maculicola ES4326. This set of ISR-primed, $P$. syringae pv. tomato- and $P$. syringae pv. maculicola-responsive genes was further analyzed in the signaling-defective genotypes.

To analyze the role of JA, ET, and SA in the regulation of the $P$. syringae $\mathrm{pv}$. tomato- and $P$. syringae pv. maculicolaresponsive genes, we compared their expression levels in wildtype Col-0 plants with those in the various signaling-defective genotypes. A gene was scored as JA-, ET-, or SA-responsive when an altered $P$. syringae pv. maculicola ES4326 response was observed in the respective mutant or transgenic compared with the wild type, or when the change in expression differed at least 1.5 -fold compared with that observed in $P$. syringae pv. maculicola ES4326-infected Col-0 plants. Of all the $278 P$. syringae pv. tomato- and $P$. syringae pv. maculicola-responsive probe sets, $12 \%$ were dependent on SA signaling only; $30 \%$ were regulated by JA signaling, ET signaling, or both; and $22 \%$ were affected by a combination of JA, ET, and SA signaling (Fig. 4, top panel). The remaining $36 \%$ of the $P$. syringae pv. tomato- and $P$. syringae pv. maculicola-responsive genes showed a similar expression pattern in all genotypes tested, indicating that their expression was not affected by either of these signals. Analysis of the ISR-primed, P. syringae pv. tomato- and $P$. syringae pv. maculicola-responsive genes revealed that only $3 \%$ were dependent solely on SA signaling, $35 \%$ of the genes were regulated by JA and ET signaling, and
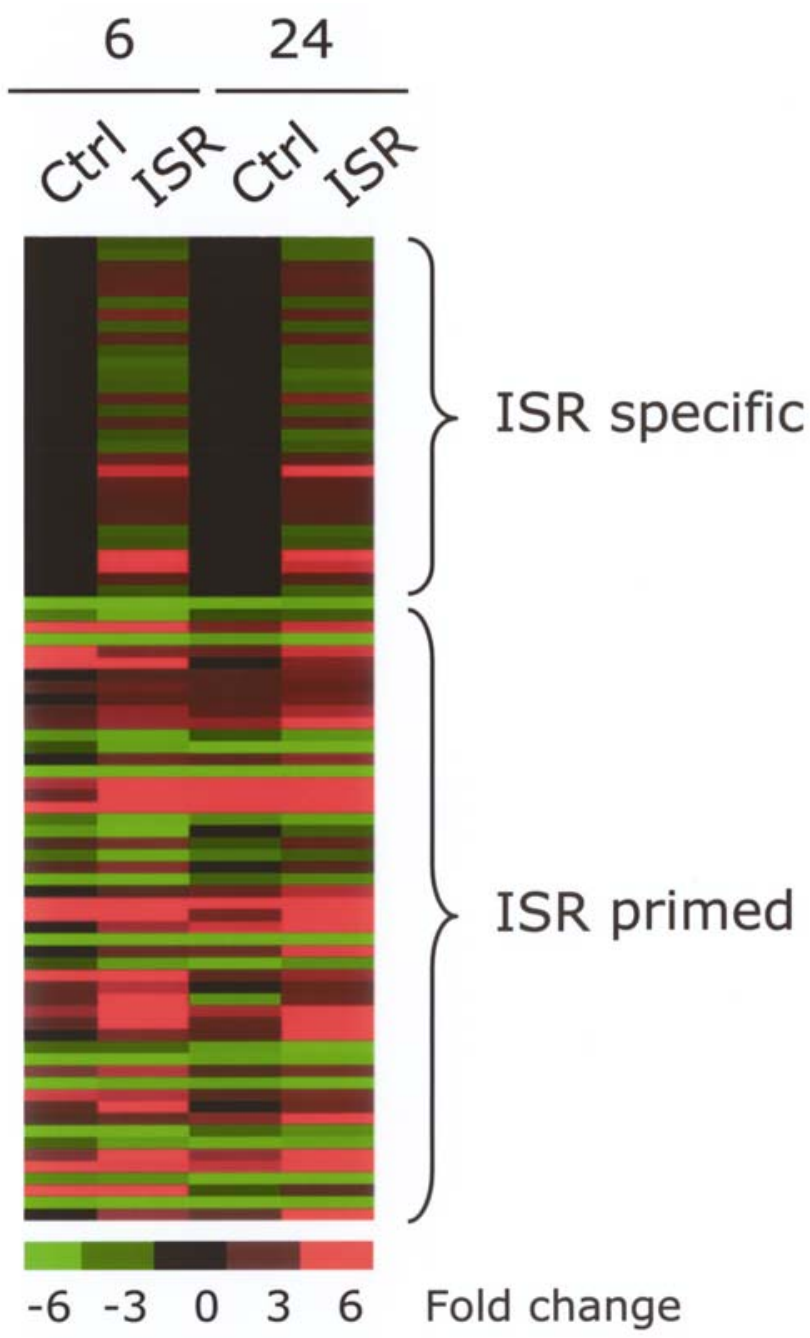

Fig. 2. Augmented expression of Pseudomonas syringae pv. tomato DC3000-responsive genes in Arabidopsis plants expressing P. fluorescens WCS417r-mediated induced systemic resistance (ISR). Comparison of the changes in transcript levels of ISR-specific and ISR-primed genes in control and ISR-expressing Col-0 plants at 6 and $24 \mathrm{~h}$ after inoculation with $P$. syringae pv. tomato DC3000. ISR-specific genes show a consistent $>$ twofold change in the level of expression at 6 and $24 \mathrm{~h}$ after inoculation, whereas these genes remained unchanged in $P$. syringae pv. tomato DC3000-inoculated control plants. ISR-primed genes display a consistent >twofold change in both control and ISR-expressing plants at 6 and $24 \mathrm{~h}$ after inoculation. In addition, the magnitude of this change is $>1.5$-fold stronger in challenged ISR-expressing plants compared with $P$. syringae pv. tomato DC3000-inoculated control plants. The values are visualized by TreeView software. 
Table 4. Fold-change ratios of induced systemic resistance (ISR)-primed Pseudomonas syringae pv. tomato DC3000-responsive genes in leaves of $P$. fluorescens WCS417r-treated plants ${ }^{\mathrm{a}}$

\begin{tabular}{|c|c|c|c|c|c|c|c|c|}
\hline \multirow[b]{3}{*}{ Annotation $^{\mathbf{b}}$} & \multicolumn{6}{|c|}{ Challenged leaves, fold-change ratio } & \multirow[b]{3}{*}{ Probe set no. } & \multirow[b]{3}{*}{ AGI no. } \\
\hline & \multicolumn{3}{|c|}{$6 \mathrm{~h}$} & \multicolumn{3}{|c|}{$24 \mathrm{~h}$} & & \\
\hline & Ctrl & ISR & Ratio & Ctrl & ISR & Ratio & & \\
\hline \multicolumn{9}{|l|}{ Transcription } \\
\hline Ethylene responsive element binding factor 2 & 12.2 & 19.8 & 1.6 & 1.0 & 3.8 & 3.8 & 12905_s_at & AT5G47220 \\
\hline WRKY family transcription factor & 2.0 & 3.1 & 1.5 & 2.2 & 2.9 & 1.3 & 13115_at & AT1G62300 \\
\hline Putative YABBY3 axial regulator & -2.2 & -4.1 & -1.9 & -5.5 & -3.8 & 1.4 & 17530_at & AT4G00180 \\
\hline Putative heat shock transcription factor & -11.8 & -23.9 & -2.0 & -4.1 & -6.6 & -1.6 & 12431 at & AT2G26150 \\
\hline \multicolumn{9}{|l|}{ Cell rescue and defense } \\
\hline Cytochrome P450 family & 4.9 & 14.2 & 2.9 & 9.8 & 28.0 & 2.8 & 14609_at & AT2G30770 \\
\hline Thaumatin-like protein & 6.3 & 17.0 & 2.7 & -2.1 & 2.2 & 4.6 & 20384_at & AT4G36010 \\
\hline Antifungal protein PDF1.2 & 3.2 & 7.9 & 2.5 & 13.4 & 31.9 & 2.4 & 14621_at & AT5G44420 \\
\hline Glycosyl hydrolase fam. 19 (chitinase) & 2.2 & 4.3 & 2.0 & 2.5 & 4.9 & 1.9 & 13153_r_at & AT2G43590 \\
\hline Glycosyl hydrolase fam. 19 (chitinase) & 2.9 & 4.5 & 1.6 & 4.4 & 7.0 & 1.6 & 13154_s_at & AT2G43590 \\
\hline Expressed protein & -22.2 & -25.2 & -1.1 & -13.9 & -25.2 & -1.8 & 16637 s_at & AT4G14690 \\
\hline Gamma-glutamyltransferase-related & -3.8 & -4.5 & -1.2 & -2.2 & -3.9 & -1.8 & 13255_i_at & AT4G39640 \\
\hline Heat shock factor protein 7 (HSF7) & -6.7 & -10.4 & -1.5 & -2.8 & -3.7 & -1.3 & 19629_at & AT4G11660 \\
\hline \multicolumn{9}{|l|}{$\begin{array}{l}\text { Cellular communication or signal transduction } \\
\text { mechanism }\end{array}$} \\
\hline Receptor-related serine/threonine protein kinase ARK3 & 1.8 & 4.7 & 2.5 & 5.7 & 12.7 & 2.2 & 16360_at & AT4G21380 \\
\hline Protein kinase-like protein & 3.7 & 8.4 & 2.3 & 4.4 & 12.3 & 2.8 & 20232_s_at & AT4G23130 \\
\hline PP1/PP2A phosphatases pleiotropic regulator PRL2 & 3.0 & 5.2 & 1.7 & 1.2 & 2.9 & 2.5 & 17954_s_at & AT3G16650 \\
\hline Ras-related GTP-binding protein (Rab7) & -3.6 & -3.7 & -1.0 & -8.7 & -14.2 & -1.6 & 20330_ā & AT1G22740 \\
\hline \multicolumn{9}{|l|}{ Metabolism } \\
\hline Short-chain alcohol dehydrogenase-like protein & 1.8 & 4.2 & 2.3 & 3.0 & 6.4 & 2.1 & 20685_at & AT4G13180 \\
\hline 2-oxoglutarate-dependent dioxygenase (AOP2) & 2.4 & 3.9 & 1.6 & 2.0 & 2.1 & 1.1 & 15238 at & AT4G03060 \\
\hline Putative cytochrome P450 & 2.1 & 3.0 & 1.5 & 4.0 & 6.5 & 1.6 & 19549_s_at & AT2G22330 \\
\hline Anthranilate synthase component I-1 precursor & 6.4 & 6.0 & -1.1 & 5.4 & 8.3 & 1.5 & 20291_at & AT5G05730 \\
\hline Arabinogalactan-protein (AGP4) & -2.9 & -4.8 & -1.6 & -3.2 & -2.4 & 1.3 & 15107_s_at & AT5G10430 \\
\hline \multicolumn{9}{|l|}{ Storage protein } \\
\hline Vegetative storage protein VSP2 & 15.1 & 23.0 & 1.5 & 143.4 & 178.6 & 1.2 & 14675_s_at & AT5G24770 \\
\hline Putative protein/storage protein & 18.0 & 25.7 & 1.4 & 10.6 & 18.7 & 1.8 & 15886_at & AT4G24350 \\
\hline Protein activity regulation & & & & & & & & \\
\hline Serpin, putative & 2.7 & 6.4 & 2.4 & -1.3 & 3.2 & 4.0 & 19322_at & AT1G47710 \\
\hline Energy & & & & & & & & \\
\hline Phosphoadenylyl-sulfate reductase (thioredoxin) & & & & & & & & \\
\hline (PAPS reductase) & -7.5 & -13.7 & -1.8 & -4.4 & -5.3 & -1.2 & 18696_s_at & AT1G62180 \\
\hline Expressed protein & -3.0 & -5.4 & -1.8 & -3.6 & -4.3 & -1.2 & 14917_at & AT2G35760 \\
\hline Glutaredoxin protein family & -2.0 & -4.4 & -2.1 & -17.6 & -17.4 & 1.0 & 13258 s_at & AT2G47880 \\
\hline Development (systemic) & & & & & & & & \\
\hline Aldose 1 -epimerase family & 1.8 & 3.2 & 1.8 & 2.7 & 4.1 & 1.5 & 13880_s_at & AT4G25900 \\
\hline No apical meristem (NAM) protein family & 4.5 & 6.5 & 1.4 & 4.9 & 8.7 & 1.8 & 18591_at & AT5G08790 \\
\hline Protein with binding function or cofactor requirement & & & & & & & & \\
\hline DEAD box RNA helicase, putative & 3.0 & 12.0 & 4.1 & -3.9 & 3.1 & 12.2 & $18016 \_$r_at & AT5G08610 \\
\hline DEAD/DEAH box RNA helicase protein, putative & 8.9 & 13.8 & 1.6 & 3.4 & 6.5 & 1.9 & 15906_at & AT1G59990 \\
\hline Zinc finger protein Zat12 & 1.5 & 2.1 & 1.4 & 2.1 & 3.3 & 1.6 & 13015_s_at & AT5G59820 \\
\hline Putative zinc-finger protein & -9.6 & -15.8 & -1.6 & -8.6 & -7.9 & 1.1 & 14504_s_at & AT2G28200 \\
\hline Subcellular localization & & & & & & & & \\
\hline Unknown protein & -1.4 & 3.6 & 4.9 & 2.4 & 11.4 & 4.7 & 18625 at & AT1G03290 \\
\hline Gamma glutamyl hydrolase, putative & 1.4 & 2.4 & 1.7 & 2.1 & 3.2 & 1.5 & 13118_f_at & AT1G78660 \\
\hline E3 ubiquitin ligase (RMA1) & 6.3 & 9.2 & 1.5 & 2.7 & 4.4 & 1.6 & 17552 s_at & AT4G03510 \\
\hline Thioredoxin family & -2.7 & -2.7 & 1.0 & -4.2 & -7.9 & -1.9 & 18637_at & AT2G42580 \\
\hline Transport facilitation & & & & & & & & \\
\hline Proline transporter 2 (ProT2) & 5.5 & 5.2 & -1.1 & 2.3 & 3.5 & 1.5 & 19158_at & AT3G55740 \\
\hline Unclassified proteins & & & & & & & & \\
\hline Expressed protein & 1.2 & 2.9 & 2.4 & 3.2 & 5.9 & 1.9 & 17010_s_at & AT2G20670 \\
\hline ACT domain-containing protein & 2.7 & 6.1 & 2.3 & 2.8 & 7.0 & 2.5 & 18624_at & AT2G39570 \\
\hline Expressed protein & 1.1 & 2.1 & 1.9 & 3.0 & 5.2 & 1.7 & 15479_at & AT4G26060 \\
\hline Expressed protein & 2.2 & 3.6 & 1.6 & -2.0 & 2.7 & 5.4 & 15063_at & AT4G12070 \\
\hline Protease inhibitor/seed storage/lipid transfer protein & -7.4 & -4.9 & 1.5 & -4.3 & -7.3 & -1.7 & $18983 \mathrm{~s}$ at & AT4G12510 \\
\hline Subunit 1 of NADH dehydrogenase & 3.6 & 5.1 & 1.4 & 2.2 & 3.4 & 1.6 & 18709_at & ATNADH \\
\hline Expressed protein & 8.0 & 11.6 & 1.4 & 3.6 & 5.6 & 1.6 & 12212 at & AT3G52070 \\
\hline Expressed protein & -4.0 & -6.3 & -1.6 & -1.8 & -2.4 & -1.4 & 14923_at & AT2G28320 \\
\hline Expressed protein & -3.3 & -5.1 & -1.6 & -2.1 & -2.4 & -1.2 & 12128_at & AT2G41010 \\
\hline Expressed protein & -2.6 & -4.1 & -1.6 & -5.3 & -4.5 & 1.2 & 19952 at & AT1G12020 \\
\hline Expressed protein & -16.2 & -28.0 & -1.7 & -5.4 & -4.5 & 1.2 & 12027_at & AT4G20170 \\
\hline Expressed protein & -5.0 & -8.9 & -1.8 & -2.7 & -3.6 & -1.3 & 15476 at & AT2G21560 \\
\hline Cathepsin B-like cysteine protease, putative & 7.4 & 3.8 & -1.9 & 3.0 & 5.6 & 1.8 & 12757_at & AT1G02300 \\
\hline Expressed protein & -5.0 & -9.9 & -2.0 & -7.0 & -5.3 & 1.3 & 20678 at & AT1G11700 \\
\hline
\end{tabular}

${ }^{a}$ Fold-change ratios (time $=6 / 0 \mathrm{~h}$ or $24 / 0 \mathrm{~h}$ ) are based on transcript profiles of leaves of control (Ctrl) and ISR-expressing Col-0 plants at 0,6 , and $24 \mathrm{~h}$ after challenge inoculation with $P$. syringae pv. tomato DC3000. Numbers in "Ratio" columns express the level of augmented expression of the ISRprimed $P$. syringae pv. tomato DC3000-responsive genes (fold-change ratio ISR/fold-change ratio Ctrl).

${ }^{\mathrm{b}}$ Annotations are as predicted by the MIPS Arabidopsis thaliana Genome Database. 
$17 \%$ of the genes were affected by a combination of JA, ET, and SA (Fig. 4, bottom panel). These results suggest that the group of ISR-primed genes is enriched for JA- and ET-responsive genes.

\section{DISCUSSION}

Rhizobacteria-mediated ISR and pathogen-induced SAR are two inducible defense responses that are controlled by distinct signaling pathways (Pieterse et al. 1998). Expression profiling of Arabidopsis plants expressing SAR revealed that this type of induced resistance is accompanied by substantial transcriptional reprogramming (Maleck et al. 2000), resulting in the accumulation of SAR gene products to levels from 0.3 to $1 \%$ of the total mRNA and protein content (Lawton et al. 1995). In this study, we analyzed the transcript profile of roots and leaves of Arabidopsis plants expressing WCS417r-mediated ISR, using a GeneChip representing approximately one-third of the Arabidopsis genome. A consistent shift in the expression of 102 probe sets (representing 97 genes) was observed in roots after colonization by WCS417r (Table 2), indicating that Arabidopsis roots respond to external stimuli perceived from this nonpathogenic rhizobacterium. These changes may be related to the roots being colonized by the bacterial strain and may be involved in the expression of localized or systemically induced resistance. The large quantity of data makes it impossible to discuss all possible functions of the identified WCS417r-responsive genes in ISR. However, in view of the ET dependency of ISR, it is worth noting that genes encoding ERF1, EREBP1, and EREBP2 are strongly down-regulated in roots that are colonized by ISR-inducing WCS417r bacteria. ERF1, EREBP1, and EREBP2 are positive regulators of ETdependent plant processes, including defense-related gene expression (Wang et al. 2002). Therefore, down regulation of the corresponding genes, as observed in WCS417r-treated roots, suggests that the onset of ISR is associated with a reduction in ET signaling. Among all of the WCS417r-responsive genes, the transcript for a flavonol reductase was observed as the most strongly induced. Flavonol reductases have been implicated in lignin and anthocyanin biosynthesis, for example (Ostergaard et al. 2001).

Although the roots clearly responded to colonization by WCS417r, we were unable to identify genes that showed a greater than twofold change in expression in the leaves of ISR-

Table 5. Fold-change ratios of induced systemic resistance (ISR)-specific Pseudomonas syringae pv. tomato DC3000-responsive genes in leaves of $P$. fluorescens WCS417r-treated plants

\begin{tabular}{|c|c|c|c|c|}
\hline \multirow[b]{2}{*}{ Annotation $^{\mathbf{b}}$} & \multicolumn{2}{|c|}{ Challenged leaves, fold-change ratio ${ }^{a}$} & \multirow[b]{2}{*}{ Probe set no. } & \multirow[b]{2}{*}{ AGI no. } \\
\hline & $6 \mathrm{~h}$ & $24 \mathrm{~h}$ & & \\
\hline \multicolumn{5}{|l|}{ Transcription } \\
\hline Hypothetical protein & 3.4 & 2.5 & 13517_g_at & AT4G18690 \\
\hline WRKY family transcription factor & 2.4 & 2.4 & 20382 s_at & AT2G30250 \\
\hline Similar to ethylene response factor 1 & 2.0 & 2.0 & 19755_at & AT2G31230 \\
\hline Squamosa promoter binding protein-related 2 & -2.0 & -2.8 & $18029 \mathrm{~g}$ at & AT5G43270 \\
\hline \multicolumn{5}{|l|}{ Cell rescue and defense } \\
\hline Putative thaumatin & 2.3 & 2.0 & 19839_at & AT2G28790 \\
\hline Expressed protein & -2.0 & -2.6 & 11995_at & AT2G29970 \\
\hline \multicolumn{5}{|l|}{ Regulation of and interaction with cellular environment } \\
\hline TAT-binding protein, putative & -2.2 & -2.1 & 14052_at & AT1G10070 \\
\hline Gluthatione reductase & -2.5 & -2.0 & 13262_s_at & AT3G54660 \\
\hline \multicolumn{5}{|l|}{ Cellular communication or signal transduction } \\
\hline Serine/threonine protein phosphatase type one (PP1) & 6.1 & 5.5 & 20333_at & AT5G27840 \\
\hline Similar to receptor kinase 1 & 2.6 & 3.5 & 16348_at & AT1G65790 \\
\hline Calcium-dependent protein kinase (CDPK) (AK1) & -2.3 & -2.4 & 16088_f_at & AT5G04870 \\
\hline Protein kinase 6-like & -2.5 & -2.5 & 19917_at & AT5G58950 \\
\hline Protein serine/threonine kinase, putative & -2.6 & -2.2 & 18316 at & AT1G01540 \\
\hline \multicolumn{5}{|l|}{ Metabolism } \\
\hline NADC homolog & 5.5 & 6.6 & 18657 at & AT2G01350 \\
\hline UDP-glycosyltransferase family & 3.0 & 2.0 & 18512_at & AT1G24100 \\
\hline Cytochrome P450-like protein & 2.4 & 2.6 & 12526_at & AT4G27710 \\
\hline Aspartate kinase-homoserine dehydrogenase & 2.3 & 2.3 & 19749 at & AT1G31230 \\
\hline Pectinesterase-related & -2.3 & -2.2 & 13635_at & AT4G12390 \\
\hline \multicolumn{5}{|l|}{ Energy } \\
\hline Glyceraldehyde-3-phosphate dehydrogenase & -2.2 & -2.5 & 20640_s_at & AT1G42970 \\
\hline Amine oxidase family & -2.6 & -2.7 & $12241 \_$at & AT4G29720 \\
\hline \multicolumn{5}{|l|}{ Protein with binding function or cofactor requirement } \\
\hline Flowering time control protein (FCA) & 2.7 & 2.1 & $13250 \mathrm{~s}$ at & AT4G16280 \\
\hline $26 \mathrm{~S}$ protease regulatory subunit $6 \mathrm{~A}$ & 2.3 & 2.5 & $14026 \_$at & AT1G09100 \\
\hline \multicolumn{5}{|l|}{ Transport facilitation } \\
\hline CLC-c chloride channel protein & 2.0 & 2.1 & 12493 g_at & AT5G49890 \\
\hline \multicolumn{5}{|l|}{ Protein fate (folding, modification, destination) } \\
\hline Putative leucine aminopeptidase & 2.1 & 2.1 & $17956 \mathrm{i}$ at & AT2G24200 \\
\hline \multicolumn{5}{|l|}{ Unclassified proteins } \\
\hline Expressed protein & 10.2 & 8.6 & 20165 at & AT1G23150 \\
\hline Expressed protein & 2.9 & 2.4 & 19218_at & AT1G54520 \\
\hline Expressed protein & -2.0 & -2.1 & 16499_at & AT4G32020 \\
\hline Expressed protein & -2.2 & -2.1 & 19984 at & AT1G61900 \\
\hline Arabinogalactan-protein (AGP3) & -2.5 & -2.9 & 15208 _s_at & AT4G40090 \\
\hline Expressed protein & -2.8 & -2.2 & 14450 at & AT1G79160 \\
\hline
\end{tabular}

${ }^{\text {a }}$ Fold-change ratios (time $=6 / 0$ or $24 / 0 \mathrm{~h}$ ) are based on transcript profiles of leaves of ISR-expressing Col- 0 plants at 0,6 , and $24 \mathrm{~h}$ after challenge inoculation with $P$. syringae pv. tomato DC3000. None of the selected genes showed a substantial change in expression in $P$. syringae pv. tomato DC3000inoculated control plants.

${ }^{\mathrm{b}}$ Annotations are as predicted by the MIPS Arabidopsis thaliana Genome Database. 
expressing plants. None of the approximately 8,000 genes tested showed a consistent change in the level of expression in the aboveground plant parts, indicating that, in contrast to SAR, the onset of WCS417r-mediated ISR in the leaves is not associated with detectable changes in gene expression. Nevertheless, leaves from induced plants displayed a clearly enhanced resistance against a broad range of pathogens. In our experiments, the effectiveness of ISR was checked for $P$. syringae pv. tomato DC3000; however, under similar conditions, ISR also was demonstrated to be effective against $X$. campestris pv. armoraciae, A. brassicicola, F. oxysporum f. sp. raphani, and Peronospora parasitica (Pieterse et al. 1996; Ton et al. 2002b). To investigate the possibility that ISR is associated with transcriptional changes that are apparent only after pathogen attack, we analyzed the expression profile of the approximately 8,000 Arabidopsis genes in control and ISR-expressing plants upon challenge inoculation with $P$. syringae pv. tomato DC3000. Of the 425 P. syringae pv. tomato DC3000-respon-

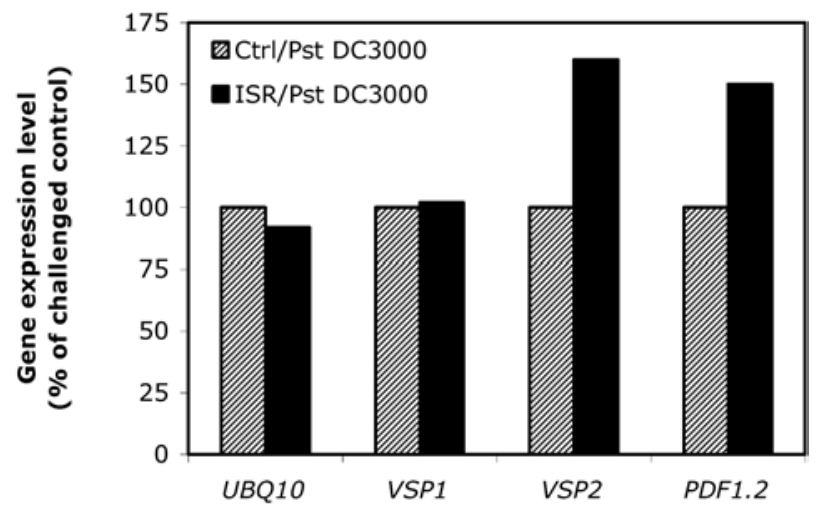

Fig. 3. Verification of leaf GeneChip data. Transcript levels of the Pseudomonas syringae pv. tomato (Pst) DC3000-responsive gene VSP1, the induced systemic resistance (ISR)-primed, $P$. syringae pv. tomato DC3000-responsive genes $V S P 2$ and PDF1.2, and the constitutively expressed gene $U B Q 10$ were analyzed in control and ISR-expressing plants at $24 \mathrm{~h}$ after inoculation with $P$. syringae pv. tomato DC3000. Hybridization signals obtained with the Northern blot analysis were quantified using a Phosphor Imager. Shown are relative transcript levels at $24 \mathrm{~h}$ after inoculation (mRNA levels in P. syringae pv. tomato DC3000inoculated control plants were set at $100 \%$ ). sive genes, 81 (19\%) showed an augmented change in ISRexpressing leaves. Of this set of ISR-primed $P$. syringae pv. tomato DC3000-responsive genes, 63\% showed an enhanced expression, whereas $37 \%$ were expressed exclusively in WCS417r-treated plants upon pathogen challenge. These results indicate that ISR-expressing plants are primed for augmented expression of a specific set of pathogen-responsive genes.

Among the ISR-primed, pathogen-responsive genes, the majority of the genes were predicted to be influenced by JA or ET signaling, suggesting that both signals play an important role. These observations can explain our previous findings that, on the one hand, responsiveness to both JA and ET is required for full expression of ISR; whereas, on the other hand, ISR is not associated with enhanced production of these hormones prior to pathogen attack (Pieterse et al. 1998, 2000). Moreover, the expression profile data are in line with previous findings that WCS417r-treated plants are primed for enhanced expression of the JA-responsive VSP2 gene and for augmented production of ET after challenge with $P$. syringae pv. tomato DC3000 (Hase et al. 2003; Van Wees et al. 1999). Hence, we postulate that colonization of the roots by ISR-inducing rhizobacteria triggers a primed state in systemic tissues, resulting in the augmented expression of specific JA- and ET-dependent defense responses upon pathogen challenge.

If this hypothesis is correct, one would expect ISR-expressing plants to exhibit an enhanced defensive capacity against pathogens that trigger, and are sensitive to, JA- or ET-dependent defenses. In a study in which the spectrum of effectiveness of rhizobacteria-mediated ISR was investigated, Ton and associates (2002b) recently demonstrated that, indeed, ISR is effective only against pathogens that are sensitive to JA- or ET-dependent basal defenses. It was postulated that ISR constitutes a reinforcement of extant JA- or ET-dependent basal defense responses, but the nature of this sensitizing effect remained unclear. Priming of JA- and ET-responsive genes allows ISR-expressing plants to respond faster or more strongly to pathogens that trigger JA- and ET-dependent defense responses; therefore, it is likely that this process plays an important role in the enhancement of JA- and ET-dependent basal defense responses during ISR.

Priming is a process that provides the plant with an enhanced capacity for rapid and effective activation of cellular defense responses that are induced only after contact with a
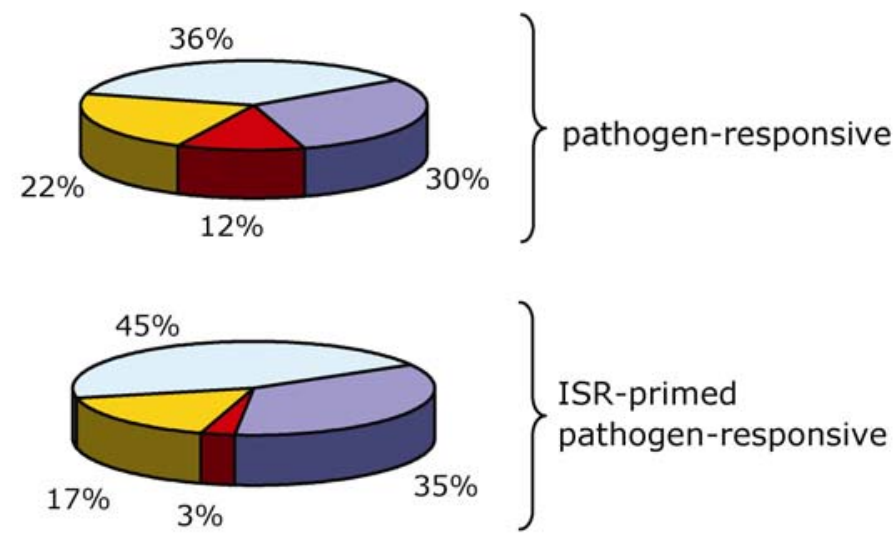

\section{$\square_{J A / E T} \square_{S A} \square_{J A} / E T+S A \quad \square_{\text {Other }}$}

Fig. 4. The group of induced systemic resistance (ISR)-primed, pathogen-responsive genes is enriched for genes that are affected by jasmonic acid (JA) and ethylene (ET) signaling. The effect of JA, ET, and salicylic acid (SA) on pathogen-responsive gene expression was assessed for 254 Arabidopsis genes that showed a similar expression pattern in Col-0 plants in response to infection by Pseudomonas syringae pv. tomato DC3000 and P. syringae pv. maculicola ES4326. Shown are the frequency distributions of the pathogen-responsive genes over the classes JA- or ET-responsive (JA/ET), SA-responsive (SA), SAand JA/ET-responsive (JA/ET+SA), and JA-, ET-, and SA-independent (other) for all the $P$. syringae pv. tomato- and $P$. syringae pv. maculicola-responsive genes and the group of pathogen-responsive genes that shows an augmented expression pattern in challenged ISR-expressing plants. 
pathogen. In the past 10 years, priming has been associated with several types of induced resistance (Conrath et al. 2002). For instance, pretreatment of parsley cell cultures with low doses of the SAR activator SA, or its functional analogues 2,6dichloroisonicotinic acid (INA) or benzothiodiazole (BTH), was demonstrated to prime the cells for potentiated activation of various cellular defense responses, in response to otherwise noninducing doses of a cell-wall elicitor from Phytophthora sojae. These potentiated responses included the early oxidative burst (Kauss and Jeblick 1995), the incorporation of various phenolics into the cell wall (Kauss et al. 1992), the secretion of antimicrobial phytoalexins (Katz et al. 1998; Kauss et al. 1992), and the potentiated expression of several defenserelated genes (Thulke and Conrath 1998). In Arabidopsis and tobacco, SAR also has been shown to be associated with priming for potentiated expression of SA-responsive $P R$ genes (Cameron et al. 1999; Kohler et al. 2002; Mur et al. 1996; Van Wees et al. 1999). Other types of induced resistance in which priming plays an important role are those triggered by the nonprotein amino acid $\beta$-aminobutyric acid (BABA) (Ton and Mauch-Mani 2004; Zimmerli et al. 2000) and bacterial lipopolysaccharide (LPS) (Newman et al. 2002). In Arabidopsis, BABA pretreatment was shown to result in a more rapid and stronger deposition of callose-containing papillae at the site of infection by the oomycetous pathogen Peronospora parasitica, or to a strong potentiation of $P R-1$ gene expression in response to infection by Pseudomonas syringae pv. tomato DC3000 (Zimmerli et al. 2000). In pepper plants, pretreatment with LPS resulted in accelerated synthesis of two antimicrobial hydroxycinnamoyl-tyramine conjugates and the potentiated expression of an acidic $P R-2$ gene in response to infection by the bacterial pathogen $X$. campestris pv. campestris (Newman et al. 2002). A common feature of the different types of induced disease resistance is that they display effectiveness against different plant pathogens. It is tempting to speculate that the broad-spectrum characteristic of induced resistance is based on the conditioning of the tissue to react more effectively to an invading pathogen.

Recently, Cartieaux and associates (2003) performed a transcriptome analysis of Arabidopsis upon colonization of the roots by the rhizobacterium $P$. thivervalensis (strain MLG45). Like WCS417r, MLG45 induced a systemic resistance that was effective against P. syringae pv. tomato DC3000. However, in contrast to WCS417r, MLG45 induced very few changes in the transcriptome of roots; whereas, systemically in the leaves, an increase in defense-related transcripts was detected prior to challenge inoculation. These results clearly contrast with ours but can be explained readily. First of all, Cartieaux and associates (2003) performed their study in Arabidopsis accession Ws-0, which is blocked in its ability to express JA- and ETdependent ISR, such as that triggered by WCS417r, due to a defect at the ISRI locus (Ton et al. 1999, 2001). By inference, WCS417r and MLG45 must induce different defense signaling pathways in Arabidopsis. Second, colonization of the roots by WCS417r stimulates plant growth in the absence of pathogen infection (Pieterse and Van Loon 1999). In contrast, MLG45 induced a clear growth reduction under such conditions (Cartieaux et al. 2003; Persello-Cartieaux et al. 2001), suggesting that the systemic changes in gene expression observed in MLG45-induced plants are likely to be caused by a more general stress response. One must conclude, therefore, that WCS417r and MLG45 induce different defense responses in Arabidopsis.

In conclusion, our study showed that the onset of WCS417rmediated ISR is not associated with detectable changes in gene expression in leaves, but rather results from the induction of a primed state, allowing augmented expression of pathogen-re- sponsive genes. The molecular mechanism of priming is still unclear. It is hypothesized that induction of the primed state results in an increase in the amount or activity of cellular components with important roles in defense signaling (Conrath et al. 2002). By itself, the increased presence or activity of these cellular signaling components have no major effect, but provide the plant with an enhanced capacity to respond to an invading pathogen. In terms of energy costs for the plant, priming might prove to be highly beneficial. On the one hand, the defense responses are expressed only when they are really needed (i.e., upon attack by a pathogen). On the other hand, only those defense responses are recruited that are triggered by the pathogen encountered. So what is the nature of the primed state of ISR? The lack of systemic changes in the expression of the approximately 8,000 Arabidopsis genes tested suggests that priming is not regulated at the transcriptional level, although crucial changes in gene expression might occur either below the level of detection or within the group of genes that was not present on the GeneChip. Alternatively, priming may be regulated post translationally. Either way, future research on the mechanism of priming will provide novel insights into how plants are able to defend themselves against harmful organisms.

\section{MATERIALS AND METHODS}

Growth conditions of rhizobacteria and plants.

Nonpathogenic $P$. fluorescens WCS417r bacteria were used for the induction of ISR. WCS417r was grown for $24 \mathrm{~h}$ at $28^{\circ} \mathrm{C}$ on King's medium B agar plates (King et al. 1954) containing the appropriate antibiotics as described previously (Pieterse et al. 1996). Subsequently, bacteria were collected and resuspended in $10 \mathrm{mM} \mathrm{MgSO}$ to a density of $10^{9} \mathrm{CFU} / \mathrm{ml}$ (optical density at $600 \mathrm{~nm}=1.0$ ) before being mixed through soil.

Seed of Arabidopsis thaliana accession Col-0 were sown in quartz sand. For isolation of RNA from roots, 2-week-old seedlings were transferred to a system of rock-wool cubes (Rockwool/Grodan B.V., Roermond, The Netherlands), as described previously (Pieterse et al. 1996; Van Wees et al. 1997). Subsequently, the root systems were covered with $1 \mathrm{ml}$ of a $1: 1(\mathrm{wt} / \mathrm{vol})$ mixture of talcum powder and either a suspension of ISR-inducing WCS417r bacteria in $10 \mathrm{mM} \mathrm{MgSO}_{4}$ (final density $5 \times 10^{8} \mathrm{CFU} / \mathrm{g}$ ), or a solution of $10 \mathrm{mM} \mathrm{MgSO}_{4}$ as a control. For isolation of RNA from leaves, 2-week-old seedlings were transferred to $60-\mathrm{ml}$ pots containing a sand and potting soil mixture that had been autoclaved twice for $20 \mathrm{~min}$ with a 24-h interval. Before transfer of the seedlings, a suspension of ISR-inducing WCS417r bacteria $\left(10^{9} \mathrm{CFU} / \mathrm{ml}\right)$ was mixed through the soil to a final density of $5 \times 10^{7} \mathrm{CFU} / \mathrm{g}$ as described previously (Pieterse et al. 1996). Control soil was supplemented with an equal volume of $10 \mathrm{mM} \mathrm{MgSO}_{4}$. Plants were cultivated in a growth chamber with a 9-h day $(200 \mu \mathrm{E}$ $\mathrm{m}^{-2} \mathrm{sec}^{-1}$ at $\left.24^{\circ} \mathrm{C}\right)$ and 15 -h night $\left(20^{\circ} \mathrm{C}\right)$ cycle at $70 \%$ relative humidity. Plants were watered once a week with water and once a week with modified half-strength Hoagland nutrient solution (Hoagland and Arnon 1938).

\section{Pathogen inoculation and ISR bioassay.}

The virulent bacterial pathogen $P$. syringae pv. tomato DC3000 (Whalen et al. 1991) was used for challenge inoculation. P. syringae pv. tomato DC3000 was grown overnight in liquid King's medium B at $28^{\circ} \mathrm{C}$. Subsequently, bacterial cells were collected by centrifugation and resuspended to a final

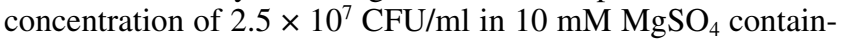
ing $0.015 \%$ (vol/vol) Silwet L-77 (Van Meeuwen Chemicals BV, Weesp, The Netherlands). To confirm expression of ISR in WCS417r-treated plants, ISR bioassays were performed as de- 
scribed previously (Pieterse et al. 1996; Van Wees et al. 1997), using a subset of plants that were grown in parallel with the plants that were used for extraction of RNA. Briefly, 5-weekold plants were placed at $100 \%$ relative humidity 1 day prior to challenge inoculation. Subsequently, plants were inoculated by dipping the leaves for $2 \mathrm{~s}$ in a suspension of $P$. syringae $\mathrm{pv}$. tomato DC3000 at $2.5 \times 10^{7} \mathrm{CFU} / \mathrm{ml}$ in $10 \mathrm{mM} \mathrm{MgSO}_{4}$ and $0.015 \%$ (vol/vol) Silwet L-77. Four days later, disease severity was assessed by determining the percentage of diseased leaves per plant. Leaves were scored as diseased when showing necrotic or water-soaked lesions surrounded by chlorosis. The disease index was calculated for each plant $(n=20)$ based on the percentage of diseased leaves.

\section{Sample preparation and microarray data collection.}

For isolation of RNA from roots and noninoculated leaf tissues, whole root systems or entire rosettes were harvested 3 and 7 days after the start of the induction treatment (see above) and immediately frozen in liquid nitrogen. For extraction of RNA from $P$. syringae pv. tomato DC3000-inoculated leaves, whole rosettes from 5-week-old, soil-grown plants were harvested at 0,6 , and $24 \mathrm{~h}$ after challenge inoculation. RNA was prepared from frozen tissue using RNAwiz (Ambion, Huntington, U.K.). Subsequently, cRNA probe synthesis, hybridization to a GeneChip, and collection of data from the hybridized GeneChip was performed as described previously (Zhu et al. 2001). Hybridizations with labeled cRNAs were conducted with Arabidopsis GeneChip Microarrays (Affymetrix, Santa Clara, CA, U.S.A.) containing probe sets for approximately 8,000 Arabidopsis genes (Zhu and Wang 2000).

\section{Expression profiling.}

Expression data were normalized globally to the average value of 100 before data analysis. Genes with accurately detectable transcript levels were defined by probe sets showing averaged expression levels greater than 40 , as described previously (Zhu and Wang 2000). For probe sets showing an expression value of $<5$, it was adjusted to 5 . The fold changes between induction treatments and the respective controls were calculated by dividing the induction-treated expression values by the control expression values. Using these selection criteria for the identification of genes displaying greater than twofold change, we expected $<0.25 \%$ false changes resulting from inaccuracies of hybridization and detection (Zhu and Wang 2000). Taking into account that, out of approximately 8,000 probe sets, only approximately 4,200 showed an expression level over 40, the number of probe sets showing false changes should be less than 11. To avoid false positives due to noise arising from variation in experimental conditions, we required the changes to be consistent in time, between experiments, or both.

\section{RT-PCR and Northern blot analysis.}

Total RNA was extracted by homogenizing frozen leaf tissue in extraction buffer $(0.35 \mathrm{M}$ glycine, $0.048 \mathrm{M} \mathrm{NaOH}, 0.34 \mathrm{M}$ $\mathrm{NaCl}, 0.04 \mathrm{M}$ EDTA, 4\% [wt/vol] sodium dodecyl sulfate, and plant tissue at $1 \mathrm{ml} / \mathrm{g}$ ). The homogenates were extracted with phenol/chloroform/isoamylalcohol (25:24:1) and the RNA was precipitated using $\mathrm{LiCl}$, as described by Sambrook and associates (1989). Analysis of gene expression in the roots was performed by RT-PCR, as described previously (Pieterse et al. 1998). Gene-specific primer pairs for the detection of $M Y B 72$, $M L O 8$, and VSP2 transcripts in the roots were designed based on the annotated sequences corresponding to AGI numbers AT1G56160 (probe set 12725_r_at), AT2G17480 (probe set 13687_s_at), and AT5G24770 (probe set 14675_s_at). Detection of the glucosyltransferase gene (probe set 17362_at, AGI number AT4G15260) and the "expressed protein" gene (probe set 18721_at, AGI number AT3G02040) was performed in a similar manner. Analysis of gene expression in the leaves was performed by Northern blot analysis. To this end, $15 \mu \mathrm{g}$ of RNA was denatured using glyoxal and dimethyl sulfoxide, as described previously (Sambrook et al. 1989). Subsequently, samples were electrophoretically separated on $1.5 \%$ agarose gels and blotted onto Hybond- $\mathrm{N}^{+}$membranes (Amersham, 's-Hertogenbosch, The Netherlands) by capillary transfer. Northern blots were hybridized with gene-specific probes as described previously (Pieterse et al. 1998). Templates for the preparation of gene-specific probes were prepared by PCR with primers based on the annotated sequences corresponding to AGI numbers AT4G05320 (UBQ10), AT5G24780 (VSP1), AT5G24770 (VSP2), and AT5G44420 (PDF1.2). After hybridization with $\alpha-$ ${ }^{32} \mathrm{P}$-dCTP-labeled probes, blots were exposed for autoradiography and signals quantified using a BioRad Molecular Imager FX (BioRad, Veenendaal, The Netherlands) with Quantity One software (BioRad).

\section{ACKNOWLEDGMENTS}

We thank A. Bent for providing P. syringae pv. tomato DC3000 and M. de Vos for critically reading the manuscript.

\section{LITERATURE CITED}

Alonso, J. M., Hirayama, T., Roman, G., Nourizadeh, S., and Ecker, J. R. 1999. EIN2, a bifunctional transducer of ethylene and stress responses in Arabidopsis. Science 284:2148-2152.

Berrocal-Lobo, M., Molina, A., and Solano, R. 2002. Constitutive expression of ETHYLENE-RESPONSE-FACTOR1 in Arabidopsis confers resistance to several necrotrophic fungi. Plant J. 29:23-32.

Bigirimana, J., and Höfte, M. 2002. Induction of systemic resistance to Colletotrichum lindemuthianum in bean by a benzothiadiazole derivative and rhizobacteria. Phytoparasitica 30:159-168.

Cameron, R. K., Paiva, N. C., Lamb, C. J., and Dixon, R. A. 1999. Accumulation of salicylic acid and $P R$ gene transcripts in relation to the systemic acquired resistance (SAR) response by Pseudomonas syringae pv. tomato in Arabidopsis. Physiol. Mol. Plant Pathol. 55:121-130.

Cao, H., Bowling, S. A., Gordon, A. S., and Dong, X. 1994. Characterization of an Arabidopsis mutant that is nonresponsive to inducers of systemic acquired resistance. Plant Cell 6:1583-1592.

Cartieaux, F., Thibaud, M.-C., Zimmerli, L., Lessard, P., Sarrobert, C., David, P., Gerbaud, A., Robaglia, C., Somerville, S., and Nussaume, L. 2003. Transcriptome analysis of Arabidopsis colonized by a plantgrowth promoting rhizobacterium reveals a general effect on disease resistance. Plant J. 36:177-188.

Conrath, U., Pieterse, C. M. J., and Mauch-Mani, B. 2002. Priming in plant-pathogen interactions. Trends Plant Sci. 7:210-216.

De Meyer, G., and Höfte, M. 1997. Salicylic acid produced by the rhizobacterium Pseudomonas aeruginosa $7 \mathrm{NSK} 2$ induces resistance to leaf infection by Botrytis cinerea on bean. Phytopathology 87:588-593.

Delaney, T. P., Friedrich, L., and Ryals, J. A. 1995. Arabidopsis signal transduction mutant defective in chemically and biologically induced disease resistance. Proc. Natl. Acad. Sci. U.S.A. 92:6602-6606.

Duijff, B. J., Pouhair, D., Olivain, C., Alabouvette, C., and Lemanceau, P. 1998. Implication of systemic induced resistance in the suppression of fusarium wilt of tomato by Pseudomonas fluorescens WCS417r and by nonpathogenic Fusarium oxysporum Fo47. Eur. J. Plant Pathol. 104:903-910.

Fan, W., and Dong, X. 2002. In vivo interaction between NPR1 and transcription factor TGA2 leads to salicylic acid-mediated gene activation in Arabidopsis. Plant Cell 14:1377-1389.

Feys, B. J. F., Benedetti, C. E., Penfold, C. N., and Turner, J. G. 1994. Arabidopsis mutants selected for resistance to the phytotoxin coronatine are male sterile, insensitive to methyl jasmonate, and resistant to a bacterial pathogen. Plant Cell 6:751-759.

Gaffney, T., Friedrich, L., Vernooij, B., Negrotto, D., Nye, G., Uknes, S., Ward, E., Kessmann, H., and Ryals, J. 1993. Requirement of salicylic acid for the induction of systemic acquired resistance. Science 261:754-756

Glazebrook, J., Chen, W. J., Estes, B., Chang, H. S., Nawrath, C., Métraux, J.-P., Zhu, T., and Katagiri, F. 2003. Topology of the network integrating salicylate and jasmonate signal transduction derived from global expression phenotyping. Plant J. 34:217-228. 
Guzmán, P., and Ecker, J. R. 1990. Exploiting the triple response of Arabidopsis to identify ethylene-related mutants. Plant Cell 2:513-523.

Hase, S., Van Pelt, J. A., Van Loon, L. C., and Pieterse, C. M. J. 2003. Colonization of Arabidopsis roots by Pseudomonas fluorescens primes the plant to produce higher levels of ethylene upon pathogen infection. Physiol. Mol. Plant Pathol. 62:219-226.

Hoagland, D. R., and Arnon, D. I. 1938. The water culture method for growing plants without soil. Calif. Agric. Exp. Stn. Bull. 347:36-39.

Iavicoli, A., Boutet, E., Buchala, A., and Métraux, J.-P. 2003. Induced systemic resistance in Arabidopsis thaliana in response to root inoculation with Pseudomonas fluorescens CHA0. Mol. Plant-Microbe Interact. 16:851-858

Katz, V. A., Thulke, O. U., and Conrath, U. 1998. A benzothiadiazole primes parsley cells for augmented elicitation of defense responses. Plant Physiol. 117:1333-1339.

Kauss, H., and Jeblick, W. 1995. Pretreatment of parsley suspension cultures with salicylic acid enhances spontaneous and elicited production of $\mathrm{H}_{2} \mathrm{O}_{2}$. Plant Physiol. 108:1171-1178.

Kauss, H., Theisinger-Hinkel, E., Mindermann, R., and Conrath, U. 1992. Dichloroisonicotinic and salicylic acid, inducers of systemic acquired resistance, enhance fungal elicitor responses in parsley cells. Plant $\mathbf{J}$. 2:655-660.

King, E. O., Ward, M. K., and Raney, D. E. 1954. Two simple media for the demonstration of phycocyanin and fluorescein. J. Lab. Clin. Med. 44:301-307.

Knoester, M., Pieterse, C. M. J., Bol, J. F., and Van Loon, L. C. 1999. Systemic resistance in Arabidopsis induced by rhizobacteria requires ethylene-dependent signaling at the site of application. Mol. Plant-Microbe Interact. 12:720-727.

Kohler, A., Schwindling, S., and Conrath, U. 2002. Benzothiadiazoleinduced priming for potentiated responses to pathogen infection, wounding, and infiltration of water into leaves requires the NPR1/NIM1 gene in Arabidopsis. Plant Physiol. 128:1046-1056.

Kreps, J. A., Wu, Y. J., Chang, H. S., Zhu, T., Wang, X., and Harper, J. F. 2002. Transcriptome changes for Arabidopsis in response to salt, osmotic, and cold stress. Plant Physiol. 130:2129-2141.

Lawton, K., Weymann, K., Friedrich, L., Vernooij, B., Uknes, S., and Ryals, J. 1995. Systemic acquired resistance in Arabidopsis requires salicylic acid but not ethylene. Mol. Plant-Microbe Interact. 8:863-870.

Leeman, M., Van Pelt, J. A., Den Ouden, F. M., Heinsbroek, M., Bakker, P. A. H. M., and Schippers, B. 1995. Induction of systemic resistance by Pseudomonas fluorescens in radish cultivars differing in susceptibility to fusarium wilt, using a novel bioassay. Eur. J. Plant Pathol. 101:655-664.

Lorenzo, O., Piqueras, R., Sánchez-Serrano, J. J., and Solano, R. 2003. ETHYLENE RESPONSE FACTOR1 integrates signals from ethylene and jasmonate pathways in plant defense. Plant Cell 15:165-178.

Malamy, J., Carr, J. P., Klessig, D. F., and Raskin, I. 1990. Salicylic acid: a likely endogenous signal in the resistance response of tobacco to viral infection. Science 250:1002-1004.

Maleck, K., Levine, A., Eulgem, T., Morgan, A., Schmid, J., Lawton, K. A., Dangl, J. L., and Dietrich, R. A. 2000. The transcriptome of Arabidopsis thaliana during systemic acquired resistance. Nat. Genet. 26:403-410.

Maurhofer, M., Reimmann, C., Schmidli-Sacherer, P., Heeb, S. D., and Défago, G. 1998. Salicylic acid biosynthesis genes expressed in Pseudomonas fluorescens strain P3 improve the induction of systemic resistance in tobacco against tobacco necrosis virus. Phytopathology 88:678-684

Métraux, J.-P., Signer, H., Ryals, J., Ward, E., Wyss-Benz, M., Gaudin, J., Raschdorf, K., Schmid, E., Blum, W., and Inverardi, B. 1990. Increase in salicylic acid at the onset of systemic acquired resistance in cucumber. Science 250:1004-1006

Mur, L. A. J., Naylor, G., Warner, S. A. J., Sugars, J. M., White, R. F., and Draper, J. 1996. Salicylic acid potentiates defence gene expression in tissue exhibiting acquired resistance to pathogen attack. Plant J. 9:559-571.

Nawrath, C., Heck, S., Parinthawong, N., and Métraux, J.-P. 2002. EDS5, an essential component of salicylic acid-dependent signaling for disease resistance in Arabidopsis, is a member of the MATE transporter family. Plant Cell 14:275-286.

Newman, M. A., Von Roepenack-Lahaye, E., Parr, A., Daniels, M. J., and Dow, J. M. 2002. Prior exposure to lipopolysaccharide potentiates expression of plant defenses in response to bacteria. Plant J. 29:487-495.

Ostergaard, L., Lauvergeat, V., Naested, H., Mattsson, O., and Mundy, J. 2001. Two differentially regulated Arabidopsis genes define a new branch of the DFR superfamily. Plant Sci. 160:463-472.

Persello-Cartieaux, F., David, P., Sarrobert, C., Thibaud, M.-C., Achouak, W., Robaglia, C., and Nussaume, L. 2001. Utilization of mutants to analyze the interaction between Arabidopsis thaliana and its naturally root-associated Pseudomonas. Planta 212:190-198.
Pieterse, C. M. J., and Van Loon, L. C. 1999. Salicylic acid-independent plant defence pathways. Trends Plant Sci. 4:52-58.

Pieterse, C. M. J., Van Pelt, J. A., Ton, J., Parchmann, S., Mueller, M. J., Buchala, A. J., Métraux, J.-P., and Van Loon, L. C. 2000. Rhizobacteria-mediated induced systemic resistance (ISR) in Arabidopsis requires sensitivity to jasmonate and ethylene but is not accompanied by an increase in their production. Physiol. Mol. Plant Pathol. 57:123-134.

Pieterse, C. M. J., Van Wees, S. C. M., Hoffland, E., Van Pelt, J. A., and Van Loon, L. C. 1996. Systemic resistance in Arabidopsis induced by biocontrol bacteria is independent of salicylic acid accumulation and pathogenesis-related gene expression. Plant Cell 8:1225-1237.

Pieterse, C. M. J., Van Wees, S. C. M., Ton, J., Van Pelt, J. A., and Van Loon, L. C. 2002. Signaling in rhizobacteria-induced systemic resistance in Arabidopsis thaliana. Plant Biol. 4:535-544.

Pieterse, C. M. J., Van Wees, S. C. M., Van Pelt, J. A., Knoester, M., Laan, R., Gerrits, H., Weisbeek, P. J., and Van Loon, L. C. 1998. A novel signaling pathway controlling induced systemic resistance in Arabidopsis. Plant Cell 10:1571-1580.

Press, C. M., Wilson, M., Tuzun, S., and Kloepper, J. W. 1997. Salicylic acid produced by Serratia marcescens $91-166$ is not the primary determinant of induced systemic resistance in cucumber or tobacco. Mol. Plant-Microbe Interact. 10:761-768.

Ross, A. F. 1961. Systemic acquired resistance induced by localized virus infections in plants. Virology 14:340-358.

Ryu, C.-M., Hu, C.-H., Reddy, M. S., and Kloepper, J. W. 2003. Different signaling pathways of induced resistance by rhizobacteria in Arabidopsis thaliana against two pathovars of Pseudomonas syringae. New Phytol. 160:413-420.

Sambrook, J., Fritsch, E. F., and Maniatis, T. 1989. Cold Spring Harbor Laboratory Press, Cold Spring Harbor, NY, U.S.A.

Schenk, P. M., Kazan, K., Wilson, I., Anderson, J. P., Richmond, T., Somerville, S. C., and Manners, J. M. 2000. Coordinated plant defense responses in Arabidopsis revealed by microarray analysis. Proc. Natl. Acad. Sci. U.S.A. 97:11655-11660.

Shah, J., Tsui, F., and Klessig, D. F. 1997. Characterization of a salicylic acid-insensitive mutant (sail) of Arabidopsis thaliana, identified in a selective screen utilizing the SA-inducible expression of the tms 2 gene. Mol. Plant-Microbe Interact. 10:69-78.

Solano, R., Stepanova, A., Chao, Q. M., and Ecker, J. R. 1998. Nuclear events in ethylene signaling: A transcriptional cascade mediated by ETHYLENE-INSENSITIVE3 and ETHYLENE-RESPONSEFACTOR1. Genes Dev. 12:3703-3714.

Tao, Y., Xie, Z. Y., Chen, W. Q., Glazebrook, J., Chang, H. S., Han, B., Zhu, T., Zou, G. Z., and Katagiri, F. 2003. Quantitative nature of Arabidopsis responses during compatible and incompatible interactions with the bacterial pathogen Pseudomonas syringae. Plant Cell 15:317-330.

Thulke, O., and Conrath, U. 1998. Salicylic acid has a dual role in the activation of defence-related genes in parsley. Plant J. 14:35-42.

Ton, J., Davison, S., Van Wees, S. C. M., Van Loon, L. C., and Pieterse, C. M. J. 2001. The Arabidopsis ISRI locus controlling rhizobacteria-mediated induced systemic resistance is involved in ethylene signaling. Plant Physiol. 125:652-661.

Ton, J., De Vos, M., Robben, C., Buchala, A. J., Métraux, J.-P., Van Loon, L. C., and Pieterse, C. M. J. 2002a. Characterisation of Arabidopsis enhanced disease susceptibility mutants that are affected in systemically induced resistance. Plant J. 29:11-21.

Ton, J., and Mauch-Mani, B. 2004. $\beta$-amino-butyric acid-induced resistance against necrotrophic pathogens is based on ABA-dependent priming for callose. Plant J. 38:119:130.

Ton, J., Pieterse, C. M. J., and Van Loon, L. C. 1999. Identification of a locus in Arabidopsis controlling both the expression of rhizobacteriamediated induced systemic resistance (ISR) and basal resistance against Pseudomonas syringae pv. tomato. Mol. Plant-Microbe Interact. 12:911-918.

Ton, J., Van Pelt, J. A., Van Loon, L. C., and Pieterse, C. M. J. 2002b. Differential effectiveness of salicylate-dependent and jasmonate/ethylenedependent induced resistance in Arabidopsis. Mol. Plant-Microbe Interact. 15:27-34

Van Loon, L. C., and Van Strien, E. A. 1999. The families of pathogenesisrelated proteins, their activities, and comparative analysis of PR-1 type proteins. Physiol. Mol. Plant Pathol. 55:85-97.

Van Loon, L. C., Bakker, P. A. H. M., and Pieterse, C. M. J. 1998. Systemic resistance induced by rhizosphere bacteria. Annu. Rev. Phytopathol. 36:453-483.

Van Peer, R., Niemann, G. J., and Schippers, B. 1991. Induced resistance and phytoalexin accumulation in biological control of fusarium wilt of carnation by Pseudomonas sp. strain WCS417r. Phytopathology 91:728-734.

Van Wees, S. C. M., De Swart, E. A. M., Van Pelt, J. A., Van Loon, L. C., and Pieterse, C. M. J. 2000. Enhancement of induced disease resistance 
by simultaneous activation of salicylate- and jasmonate-dependent defense pathways in Arabidopsis thaliana. Proc. Natl. Acad. Sci. U.S.A 97:8711-8716.

Van Wees, S. C. M., Luijendijk, M., Smoorenburg, I., Van Loon, L. C., and Pieterse, C. M. J. 1999. Rhizobacteria-mediated induced systemic resistance (ISR) in Arabidopsis is not associated with a direct effect on expression of known defense-related genes but stimulates the expression of the jasmonate-inducible gene Atvsp upon challenge. Plant Mol. Biol. 41:537-549.

Van Wees, S. C. M., Pieterse, C. M. J., Trijssenaar, A., Van 't Westende, Y A. M., Hartog, F., and Van Loon, L. C. 1997. Differential induction of systemic resistance in Arabidopsis by biocontrol bacteria. Mol. PlantMicrobe Interact. 10:716-724.

Wang, K. L.-C., Li, H., and Ecker, J. R. 2002. Ethylene biosynthesis and signaling networks. Plant Cell 14:S131-151.

Ward, E. R., Uknes, S. J., Williams, S. C., Dincher, S. S., Wiederhold, D. L., Alexander, D. C., Ahl-Goy, P., Métraux, J.-P., and Ryals, J. A. 1991. Coordinate gene activity in response to agents that induce systemic acquired resistance. Plant Cell 3:1085-1094.

Whalen, M. C., Innes, R. W., Bent, A. F., and Staskawicz, B. J. 1991 Identification of Pseudomonas syringae pathogens of Arabidopsis and a bacterial locus determining avirulence on both Arabidopsis and soybean. Plant Cell 3:49-59.

Xie, D. X., Feys, B. F., James, S., Nieto-Rostro, M., and Turner, J. G. 1998. COI1: An Arabidopsis gene required for jasmonate-regulated de- fense and fertility. Science 280:1091-1094.

Yan, Z., Reddy, M. S., Ryu, C.-M., McInroy, J. A., Wilson, M., and Kloepper, J. W. 2002. Induced systemic protection against tomato late blight elicited by plant growth-promoting rhizobacteria. Phytopathology 92:1329-1333.

Zhang, S., Moyne, A.-L., Reddy, M. S., and Kloepper, J. W. 2002. The role of salicylic acid in induced systemic resistance elicited by plant growth-promoting rhizobacteria against blue mold of tobacco. Biol. Control 25:288-296.

Zhu, T., Budworth, P., Han, B., Brown, D., Chang, H. S., Zou, G. Z., and Wang, X. 2001. Toward elucidating the global gene expression patterns of developing Arabidopsis: Parallel analysis of 8300 genes by a high-density oligonucleotide probe array. Plant Physiol. Biochem. 39:221-242.

Zhu, T., and Wang, X. 2000. Large-scale profiling of the Arabidopsis transcriptome. Plant Physiol. 124:1472-1476.

Zimmerli, L., Jakab, G., Métraux, J.-P., and Mauch-Mani, B. 2000. Potentiation of pathogen-specific defense mechanisms in Arabidopsis by $\beta$ aminobutyric acid. Proc. Natl. Acad. Sci. U.S.A. 97:12920-12925.

\section{AUTHOR-RECOMMENDED INTERNET RESOURCE}

The MIPS Arabidopsis thaliana genome database : mips.gsf.de/proj/thal/db/index.html 